Article

\title{
Affordable Housing Provision in Informal Settlements through Land Value Capture and Inclusionary Housing
}

\author{
Bernard Nzau* (D) and Claudia Trillo (D) \\ School of Science, Engineering and Environment, University of Salford, Manchester M5 4WT, UK; \\ c.trillo2@salford.ac.uk \\ * Correspondence: B.Nzau@edu.salford.ac.uk
}

Received: 29 June 2020; Accepted: 18 July 2020; Published: 24 July 2020

\begin{abstract}
Public-driven attempts to provide decent housing to slum residents in developing countries have either failed or achieved minimal output when compared to the growing slum population. This has been attributed mainly to shortage of public funds. However, some urban areas in these countries exhibit vibrant real estate markets that may hold the potential to bear the costs of regenerating slums. This paper sheds light on an innovative hypothesis to achieve slum regeneration by harnessing the real estate market. The study seeks to answer the question "How can urban public policy facilitate slum regeneration, increase affordable housing, and enhance social inclusion in cities of developing countries?" The study approaches slum regeneration from an integrated land economics and spatial planning perspective and demonstrates that slum regeneration can successfully be managed by applying land value capture (LVC) and inclusionary housing (IH) instruments. The research methodology adopted is based on a hypothetical master plan and related housing policy and strategy, aimed at addressing housing needs in Kibera, the largest slum in Nairobi, Kenya. This simulated master plan is complemented with economic and residual land value analyses that demonstrate that by availing land to private developers for inclusionary housing development, it is possible to meet slum residents' housing needs by including at least $27.9 \%$ affordable housing in new developments, entirely borne by the private sector. Findings suggest that under a robust public-led governance umbrella, market forces can (1) significantly contribute to fill the financial gap in order to achieve the end of slums by 2050 in coherence with the United Nations Agenda 2030 targets and principles, and (2) increase both affordable and market housing in upgraded neighbourhoods, hence enhancing social inclusion in cities of developing countries.
\end{abstract}

Keywords: slum regeneration; affordable housing; inclusionary housing; land value capture; social inclusion

\section{Introduction}

Low-income households in cities of Africa and other developing regions are faced with an acute housing affordability challenge. In these cities, housing has become unavailable and unaffordable [1,2] partly because housing markets have become distorted and dysfunctional [3], working against the interests of the urban poor. The rate of urbanization in most of these countries has increased rapidly [3] and this, coupled with poor urban governance [4,5], has worsened the housing affordability challenge. The problem is more acute in Sub-Saharan Africa as data from UN-Habitat show [6]. According to UN-Habitat, the urban slum population in all developing countries increased from 689 million in mid-1990 to 881 million in mid-2014, an increase of $27.8 \%$. Within the same period the urban population living in slums in Sub-Saharan Africa dramatically increased from 93 million to 200 million, 
an increase of $115 \%$. About 1 billion people currently live in slum settlements-almost a third of the world's urban population - and this is projected to double by 2030 [7] and could increase to 3 billion by 2050 [8]. This calls for urgent measures to increase the supply of affordable housing for the low-income households [9].

Though there has been progress in improving the living conditions of many slum dwellers over the years, this has been negatively offset by overwhelming slum growth [10]. Millington and Cleland [7] observed that during the last 50 years, governments have implemented a wide range of slum upgrading projects and programmes of varying scale and scope that have improved the lives of many slum dwellers. However, despite this the growth of slums and informal settlements is only getting worse, particularly in developing countries, and the total number of slum dwellers has increased [7]. This scenario is greatly undermining the ability of cities in developing countries to economically grow, prosper, and generate wealth [11].

So far, public-driven attempts to provide decent housing to slum residents have failed, mainly because of the shortage of public funds. The increased urban populations coupled with the rapid growth of slums in developing countries make it clear that cities in these countries will have no institutional, infrastructural, and financial capacity to satisfactorily accommodate all urban dwellers if alternative innovative approaches are not devised. Tito and Somik [9] argued that there is little clarity in approaches to slum regeneration in terms of (i) interventions that are most effective; (ii) the sustainability of alternate programmes and their relative cost effectiveness, and (iii) the citywide consequences of these interventions. Attempts at regenerating slums have mainly been based on governmental and non-governmental organisation (NGO) efforts, with very little results. As the World Bank [12] (p.ix) argues, "narrowly-focused, neighbourhood-level slum upgrading interventions, while generally effective, have fallen short of addressing the magnitude and scope of expanding informality and slums". Many slum upgrading projects have been community-led and have met the UN-Habitat best practices but the upgrading process has "remained outside mainstream urban planning and management" [11] (p.vii), and the output has been minimal when compared to the growing slum population. These challenges highlight the valuable contribution that integrated and participatory slum upgrading has to offer to the sustainable development of humankind, as it addresses the pressing needs of the growing numbers of the urban poor [6]. Therefore, as Baker and McClain [13] observed, when policy makers and planners make consideration for the scaling up of slum upgrading projects, there is a need to look beyond the public sector. Existing approaches for the provision of affordable housing are inadequate to the challenge faced in cities, and there is a need to test new innovative approaches for funding, especially in slum upgrading [14]. The public sector cannot do it alone and there is much need for alternative approaches [13]. One such approach with huge potential is engaging the private sector developers by attracting their finances and expertise through innovative land-use incentives that could benefit both the private investors and the public. This is because in most urban areas the real estate market is vibrant and highly dynamic and may hold the potential of bearing the costs of regenerating slums.

In Kenya, our case study country, we found that there was a lot of literature on informal settlements, but most of it was entirely focused on the problem of slums and evaluation of the slum upgrading projects undertaken by the government [15-19]. Mutisya and Yarime [15] gave a conceptual analysis of the dynamics of urban sustainability and slums development and reviewed the historical perspectives and realities of the Kibera slum in Nairobi. They found that the government and other partnering organizations have devised no new applicable ideas to tame the development and growth of slums in the city. Mutisya and Yarime therefore concluded that "the problem of unsustainable urban growth in Kenya is not just about poverty but the poverty of ideas" [15] (p.210). Cronin and Guthrie [16] focused on the improvement of water and sanitation infrastructure and services in the Kibera slum and found that slum improvement through multi-stakeholder involvement is more successful than the 'top-down' government approach. Other recent studies have concentrated on evaluating the Kibera Kenya slum upgrading project (KENSUP) [17-19]. There is no research that tries to offer alternative and sustainable 
means of slum and informal settlement upgrading in Kibera and other slums in the country. Sustainable Development Goal (SDG) 11 (target 11.1) requires that "by 2030, ensure access for all to adequate, safe and affordable housing and basic services and upgrade slums", this target being measured by monitoring the "proportion of urban population living in slums, informal settlements or inadequate housing"-indicator 11.1.1 [20]. The connection between SDGs, slum regeneration, and sustainability is attracting growing interest in the literature [21]. This paper aims at contributing to the pursuing of the SDG 11, Target 11.1, by shedding light on an innovative hypothesis to achieve slum regeneration by harnessing the real estate market. With this aim, it approaches the slum regeneration issue from an integrated land economics and spatial planning perspective and demonstrates that slum regeneration can be successfully managed by applying land value capture (LVC) and inclusionary housing (IH) instruments. In so doing, it fills a gap in the current knowledge, since the connection between land value capture and housing affordability and its potential applicability to slum regeneration has not been thoroughly explored so far.

Although a robust scholarship exists on LVC in both developed and developing countries [22-28], still, a paucity of studies on LVC and affordable housing in slum regeneration persists. As Wyatt [26] argued, affordable housing delivery as an LVC mechanism is not so well-documented, hence it is not clear how effective it is. The Committee on Housing and Land Management of the Economic Commission for Europe at the United Nations recently (2-4 October 2019 meeting in Geneva) recognized that "while there are many studies which include information and examples on how national and local governments implement value capture policies, there are still few studies which would demonstrate the connection between land value capture and housing affordability" [29] (p.3). Very little has been explored so far on public-private-based approaches to develop a market-driven slum regeneration process, possibly due to the limitations of the social construct underpinned in the concept of "slum" or "informal settlement" so far [5]. To the researcher's knowledge, only Freire [30] discussed the connection between land value capture and slum regeneration in São Paulo, but without suggesting and demonstrating an extensive application of the former to the latter as this paper does.

\section{The Challenge of Slums and Urban Poverty}

According to UN-Habitat [6], a slum refers to a variety of settlements that display a combination of poor housing conditions, lack of basic infrastructure, insecurity of tenure, and various kinds of environmental risks and includes a variety of settlements such as shanty towns, squatter settlements, informal illegal subdivisions, dilapidated inner city housing, overcrowded tenements, villages within cities, and deteriorating public housing. A slum household is defined by UN-Habitat [31] (p.17) as consisting of one or a group of individuals living under the same roof in an urban area, lacking one or more of the following five amenities: (i) durable housing (a permanent structure providing protection from extreme climatic conditions); (ii) sufficient living area (no more than three people sharing a room); (iii) access to improved water (water that is sufficient, affordable, and can be obtained without extreme effort); (iv) access to improved sanitation facilities (a private toilet, or a public one shared with a reasonable number of people); and (v) secure tenure (de facto or de jure secure tenure status and protection against forced eviction).

Slums are an important part of the urban economy [32], fulfil important political, social, and economic functions in the city [33], form part of the informal economy, and house many of the informal economy's actors [13]. In the absence of the alternative affordable housing that is available in the slums, the urban economy would be affected. Therefore, slums cannot be ignored and effective sustainable public policies need to be put in place to guide and accelerate their improvement. Improving housing for slum dwellers and transforming their lives, particularly through participatory partnership programmes, lie at the heart of the 2030 Agenda for Sustainable Urban Development Goals (SDGs), targets, and indicators, as they "directly contribute to the five areas of critical importance for humanity identified by the said agenda: People, Prosperity, Planet, Peace and Partnership" [6] (p.83). Of critical importance is the contribution to SDG 11, which requires cities and human settlements to be 
made inclusive, safe, resilient, and sustainable [20]. Slums improvement will also contribute to ending global poverty, particularly the urban poverty represented by the many slum dwellers [34].

Causes of slums have been widely researched. In general, there are two main reasons why slums develop: population growth and governance [4]. Slums are a product of urban growth and rural urban migration [5]. As El-hadj et al. [3] argued, the failure of the housing market in African cities is also a main reason for the existence and growth of slums. Such market failure means the poor and the low-income households cannot access affordable housing in the formal market and, hence, slums provide the only reasonable and affordable housing option for them. Slums thrive because of the inadequacy of both public and market responses to the plight of the urban poor [34]. According to Baker and McClain [13], slums are essentially a private phenomenon, which responds to market incentives and distortions without extensive government interference. Baker and McClain further indicated that slums thrive and grow because a significant amount of economic activity contributes to the provision of basic shelter, water, food, energy, and other goods to slum dwellers. Factors often cited as causes of slums include poor government policies, the failure of the market and government to meet the enormous demand for decent and affordable housing, low state investment in infrastructure, an ineffective urban planning system, resource deficiencies, and a misdirected regulatory system [35]. Other factors supporting growth of slums include "a combination of rapid urbanization and demographic growth, bad policies, and inappropriate incentive systems including poor governance, inappropriate regulatory frameworks, dysfunctional housing markets, and a lack of political will" [3] (p.216). Above all, poverty pushes urban dwellers to slums because of their inability to afford high rents charged in the formal housing market [36,37]. Actually, slums represent the worst of urban poverty and inequality [34]. Poor urban governance by city authorities reflected in poor enforcement of urban development and the use of rigid and often outdated urban planning regulations, which are often bypassed by slum dwellers to meet their housing needs, have also accelerated slum formation [5,36,38]. Assefa and Peter [21] pointed out that the increased inequality and exclusion exhibited by slums is a consequence of the failure of public and private investment in pro-poor urban and housing development. The World Bank [12] noted that many cities today face expanding informality at the urban fringe because of failure to adjust urban planning regulations to allow for greater density in tandem with urbanization.

Lack of a land-use incentive system has supported the persistence and proliferation of slums. Therefore, there is a need for appropriate public policy and legislation to support affordable housing because political and economic opportunists in slum areas continue to thrive as a result of ineffective legislative and regulatory control [3]. Powerful and well-connected influential groups and individuals continue to benefit from the status quo [35] as the poor continue to live in desperate conditions. In Africa, this is particularly true for highly populated slums located in prime public land. This "inefficiency of the governance and spatial planning systems" [3] (p.41), coupled with the political and economic capitalization of slums in cities, creates a situation that leaves slum dwellers at the mercy of the slumlords who claim the land and the structures thereon. Some of the slumlords are influential people in society who do not live in the slums; for example, a survey by El-hadj et al. [3] found that some of the people who claim the land where the Kibera slum in Nairobi sits are wealthy individuals, including civil servants, politicians, and medical doctors. They live and own land elsewhere in the city and use the land and structures they have developed in Kibera as rental investment.

Failure of implemented slum policies and poor urban governance in general are interrelated factors that have facilitated the propagation of slums [5], and this is due to the inability of governments to understand fully the needs of slum dwellers and incorporate their needs when developing appropriate policies [39]. Governments in many less developed countries have failed (i) to incorporate slum dwellers in the overall planning process [4] and (ii) to understand the locational decisions of slum dwellers, and have insisted on resettlement in less desirable areas that the former slum dwellers leave as soon as they are settled. As Cities Alliance [4] argued, relocating slum residents far from their original homes and job opportunities is not usually viable. In designing more appropriate slum policies, 
all these issues need to be considered holistically because they are all important, and as Ron et al. [5] argued, failure to do so will only lead to the continued growth and persistence of slums.

We narrowed the location of our case study down to Kenya because UN-Habitat [40] indicated that $50 \%$ of Nairobi residents experience some form of shelter deprivation. UN-Habitat further argued that the urban poverty experienced by a majority of city residents is a result of institutional failures that perpetuate inequalities and social exclusion of the urban poor. That is why UN-Habitat [41] emphasized that there is a need for strong and effective housing policies that promote an end to these injustices faced by the poor. This is important because, as Jacobus [42] (p.10) argued, "equitable development benefits not only lower-income households; integrated, inclusive, and diverse communities enhance the lives and outcomes of all residents".

\section{Challenges in Slum Upgrading}

Slum upgrading involves many actors and interrelated factors [43] and can therefore be challenging in terms of planning and decision-making. Most of the challenges facing slum upgrading are related to (a) the land the slums sit on and (b) the slum dwellers residing on the land. Slum dwellers do not have a legal claim to the land they occupy. In addition, in some cases the land they occupy may be unsuitable for development. For instance, approximately $5 \%$ of land occupied by the slum settlements in Nairobi is unsuitable for human settlement [44] because it is either sloppy, swampy, or on river beds. Where alternative land for resettlement needs to be sought, it becomes almost impossible for both national and local governments to find the same in prime accessible locations because most cities face dysfunctional and/or distorted land markets that are supported by inappropriate building standards and land regulations [4]. There are also external interests in the land occupied by Nairobi slums such as Kibera and Majengo because of their prime location [44]—-they are centrally located near the city centre. These external interests slow the upgrading process and even where such slums are upgraded, they end up benefitting the middle-income households rather than the slum dwellers. Because of the high settlement densities in slums, available land in most cases cannot accommodate the existing slum population. For this reason, slum upgrading may involve relocations of slum dwellers. This goes against the best practise of in situ slum upgrading as advocated by UN-Habitat. In situ upgrading ensures the continued and uninterrupted social fabric and interdependence for the benefit of households and the local urban economy. Relocating slum dwellers can lead to serious socioeconomic effects such as interruption of the residents' daily activities, long distances to workplaces, or even unemployment [19].

In some instances, slum residents refuse to surrender the land they occupy and demand compensation before doing so, and this impacts on the progress and success of the upgrading programmes. For example, in one upgrading project in the Soweto East area of the Kibera slum in Nairobi, there was a demand for compensation from structure owners, whereas in another project in the Silanga area within the same slum residents voluntarily and freely gave away their land [16]. There was more success in project implementation in the latter compared with the former.

There are challenges in organizing all stakeholders in the slum community to achieve coherence and find lasting solutions to all the different needs and demands that arise [4]. For instance, in the Kibera slum, different stakeholders, including the local administration (chiefs), politicians, religious and cultural leaders, and non-governmental organizations operating in the slum, have had varying and conflicting inclinations and competing interests. This has contributed to creating suspicion, mistrust, and conflict, thus slowing down decision-making and the upgrading progress [45]. In such cases and most of the time, it is the interests of politicians that carry the day, irrespective of whether they are in tandem with the interests of the majority poor living in the slums. This could be why Elmhirst [46] argued that slum improvement programmes and projects form part of political survival strategies and avenues meant to manipulate the poor for the selfish interests of the political class. Amis and Kumar [47] (p.196) summarised it well-" the task is to implement; the problem is to overcome the political and economic constraints". Therefore, as Amis and Kumar emphasized, to succeed, slum 
upgrading needs good political will for effective project facilitation and implementation. A city's political context has the power to affect even the upgrading financing mechanisms [14].

While some governments have displayed some level of political will to deal with the slum problem, many others completely lack the same [48]. Overall, many governments have paid little attention to both (i) the challenges that have enabled the continuous growth and spread of slums and (ii) the plight of slum dwellers themselves [5]. Moreover, competing interests among stakeholders slow down upgrading initiatives [45], and some NGOs may promote social activism, thus constraining progress [49]. Conflicts between tenants and slumlords also abound in slum upgrading projects. In Kenyan slums, nearly $85 \%$ of slum dwellers are tenants [45] and their interests are different from those of the slumlords. While slumlords are interested in securing their structures and the land they sit on, tenants are concerned about accessing affordable housing. Some slum upgrading projects have failed because of resistance from some community members and groups who believe or fear that they will not qualify to be allocated housing units under the upgrading programmes [4].

UN-Habitat [34] also identified social segregation as a major challenge to slum upgrading programmes. Segregation, social disparity, and marginalization are sometimes manifested through exclusion of the slum dwellers in the planning, the upgrading process, and jobs allocation in the upgrading projects, further hurting the local economy [50]. As Werlin [51] pointed out, most slum upgrading programmes concentrate mostly on housing improvements and ignore other slum livelihoods that are equally important. There is a need for comprehensive and integrated slum upgrading intervention covering affordable housing provision, micro and small enterprise support, and local employment to enhance the acceptability and impact of the programmes [14].

Implementing slum upgrading requires huge financial resources for infrastructural and housing development. These costs are mostly borne by governments and donors [3], and lack of adequate finance remains a big challenge to eliminating slums in developing countries. Many governments lack the resources to prevent formation of slums and upgrade existing ones [5,39,52]. Most donors have scaled down their support in the recent years [17], and governments are facing critical challenges in mobilising financial resources [14]. Cytonn [53] identified the key challenges hindering provision of affordable housing in Kenya to be the high land costs, high construction and infrastructural costs, and inadequate access to financing.

\section{Slum Regeneration Policies So Far}

Policy response to the urban slum problem in Kenya and other developing countries has evolved over the years. According to UN-Habitat [35], governments have historically responded to the problem of slums in seven main ways: ignoring them; using slums for political purposes; eradication, eviction, and displacement; relocation; public housing; sites and services schemes; and upgrading. In the past, the Kenyan government has made attempts aimed at increasing affordable housing for its citizens. From the 1930s to the early 1960s, the government invested in public housing. However, as Mwaniki et al. [54] outlined, in 1964 the government reduced its allocation to public housing provision due to low financial resources. This action accelerated development of slums and informal settlements in the country's cities, especially Nairobi. Mwaniki et al. further observed that in the early years of independence the state viewed slums as an eyesore to the city's image and development prospects. The government responded with harsh strategies to clean the cities, including mass evictions of squatters and clearance of slums. In fact, according to UN-Habitat [35], evictions and segregation became common in Nairobi, among other African cities including Cape Town, Kinshasa, and Harare. Because of prevalent slum clearance, governments were destroying more low-income housing annually than they were building [46], worsening the housing problem.

Scholars such as Turner and Fichter [55] cautioned governments against total clearance of slums and emphasized the need to adopt strategies for protecting and conserving the environment even in the presence of slums. Turner and Fichter argued that if governments could improve the sanitary conditions and environmental quality of slum areas, then residents would progressively improve 
their houses, especially when assured of the security of land tenure. In the 1970s, governments began to recognise slums as urban realities that required adequate solutions [21]. There have been shifts in policy doctrine since the 1970s, from emphasizing evictions and resettlement to an approach of integrating slums into housing policies in the 1980s, to providing for land tenure regularization and housing finance in the 1990s, and to combined approaches of housing development and infrastructure improvements [21].

In Kenya, other strategies implemented in the 1980s included site-and-service schemes as well as slum upgrading programmes with assistance from international financiers. In the early 2000s, the Civil Servants Housing Scheme Fund was established to facilitate affordable housing provision for civil servants [56]. In 2017, the government unveiled the Affordable Housing Programme (AHP) as one of its big four agendas with a target to deliver 500,000 affordable houses by 2022 [57]. The State Department for Housing and Urban Development presented an AHP framework that encourages the participation of the private sector and proposes incentives such as tax breaks, provision of serviced land, standardized housing designs, and legal reviews to facilitate affordable housing provision. However, AHP progress has been slow, and according to an analysis by Seeta [58], the few units already produced are being sold at prices higher than what was promised under the government's original AHP framework, thus making them unaffordable to low-income households. Even with all the above strategies having been tried over the years and a Constitution supporting adequate housing for all, the slum problem has refused to disappear and housing affordability remains a thorn in the flesh of the government. The housing market in Nairobi and other cities remains robust but continues to work against the poor.

Nowadays, policies on slum improvement are formulated with recognition of the slum dwellers' right to the city as included in the United Nations Rights to Housing [59]. The "Right to the City" seeks to promote equal access to the potential benefits of the city for all urban dwellers and encourages their democratic participation in decision-making processes in their cities [3]. Lately, there has been a strong commitment in most countries to a better and more modern approach of replacing slums with high-rise complexes. However, there is a problem - most projects have involved slum relocation with the high-rise complexes being developed on the outskirts of cities, where basic social and economic services are unavailable [21]. Even where they are undertaken in situ (where the slums exist), the output is minimal and almost insignificant compared to the magnitude of the housing problem. This is the case for Nairobi, and as UN-Habitat [35] reports, the city continues to be dominated by slums and informal settlements, characterized by poor living conditions and extremely high population densities.

\section{Towards a Sustainable Approach to Slum Upgrading}

Cities Alliance [4] pointed out three key issues for governments and stakeholders to consider in formulating policies that facilitate affordable housing provision for the urban poor. First is the need to accept the reality of urban growth and plan for it. Second is a shared understanding that slums and their residents are an integral part of the city; and third is that slum residents have a right to the city and to its services. There is a need to embrace sustainable approaches to slum upgrading in order to provide decent housing to the urban poor. As the United Nations [60] argued, what is needed is an inclusive and sustainable approach to urban development, one that can enable cities to cope with slums so that their future is safeguarded. To achieve this, the United Nations advised that authorities must clearly identify barriers to effective slum regeneration and introduce incentives for change. For SDG target 11.1 to be achieved, it will need to be owned by all stakeholders, including national and local authorities who should develop participatory slum upgrading strategies and programmes devoid of forced evictions [21]. This is important because "the challenge of informal settlements is complex as evidenced from their persistence after decades of planning and therefore, tackling them requires new approaches and ideas" [54] (p.16,17). In the face of the huge challenge of housing the urban poor living in slums, "urban planning must become more efficient and forward-looking, in order to enhance urban densities and reduce transportation needs, cut per-unit land costs, provide more 
efficient and affordable basic services as well as improved living environments for all citizens" [41] (p.9). The housing problem in cities has become worse while cities' economies and real estate markets have become more robust. Therefore, tools are required that capture this urban dynamism in order to meet the rising housing needs. "A system is often required to redefine itself and reinvent itself to meet new challenges and accommodate new needs" [61] (p.2).

El-hadj et al. [3] suggested two key ways to stop the expansion of existing slums and prevent development of new ones. The first is to effectively address the supply failures of the housing market. The second is to provide affordable housing alternatives for the poorest, while bearing in mind that there is also a dearth of affordable housing alternatives for middle-income households. This calls for an approach that will lead to an increase in both low-income and middle-income housing, preferably in a mixed spatial setup, hence enhancing social inclusion. This will improve the living conditions of the slum dwellers as well as their economic welfare. In order to achieve sustainable slum improvement, governments will need to adopt comprehensive and integrated approaches supported by a range of policy tools that assure better outcomes [21].

In order to develop and implement effective interventions in slums, there is a need for new policies and an understanding of the role of the land and housing market. New participatory and inclusive approaches that explore new innovative and effective financing avenues are needed [60]. For slums to be eliminated, critical governance, economic, and political-cultural reforms that cater to the interests of the urban poor must be implemented [62]. UN-Habitat [11] suggested regeneration of slums through a planning process of opening streets, or reinforcing and improving existing streets and access paths. The World Bank's urban strategy supports approaches that embrace efficient use of space, address congestion, promote social inclusion, and harness urbanization to deliver equitable housing production, inclusive growth, and a reduction in urban poverty [12].

Where land tenure in slums has been regularized to private individuals, governments should find ways of recouping the cost of slum regeneration through either levying land rates or charging households for outright purchase of the land [3]. It seems prudent to promote the private sector in housing development because, as the World Bank [12] observed, when the public sector dominates the private sector in land development, land market outcomes in cities are on average less favourable in terms of housing affordability and access to land by firms. The World Bank further observed that cities that auction public land, as well as those that do limited or no land banking, also tend to have more affordable housing. However, if the housing crisis in the inner cities is to be solved, there is a need for a change of land-use regulations to allow for higher densities [14], accompanied by a well-designed land value capture mechanism to finance affordable housing provision. This approach will enable governments to tap financial resources from the private sector.

\section{Land Value Capture, Inclusionary Housing and Slum Regeneration}

That there is an active informal land market in slums is not in doubt. The process by which the illegal subdivisions and land allocation is done in slums is similar to what happens in the formal land markets. Transactions are totally market-based and, just like in the formal markets, prices are guided by the size and quality of the land itself, level of perceived security of tenure, location of the land in terms of proximity to roads, bus termini, shops, and employment centres [34,63]. As Baker and McClain [13] observed, before slums benefit from any NGO or government interventions including upgrading, existing developments are exclusively done by the informal private sector. As Baker and McClain pointed out, this highlights the market system on which slums rely and could be the basis for envisioning and proposing an expanded role for the formal private sector in the slums.

Relying on public or external funding has been the main impediment to slum upgrading. This research considers the rationale and potential of using land value capture to increase affordable housing in the city of Nairobi. The research hypothesizes that slums could best be regenerated through conversion of public land (where most slums sit) to private land through alienation to private developers who include the slumlords. This methodology is proposed for slums and informal 
settlements on public land where, through stakeholder participation, land would be planned and allocated with priority going to the structure owners with the ability to develop, but also extending the offer to market developers. The conversion of the land from public to private status with high density use (high-rise flats) and its planning will enhance its value. Such value enhancement needs to be harnessed for the public good through a land value capture (LVC) mechanism. LVC means "requiring and using for public benefit part of any increment in land value that results from public policy and/or investment (and not by direct action by the landowner)" [64] (p.2,3). If this increment is not captured, it will end up benefitting the new landowners only and would have harmful effects on the low-income slum residents as it will result in their displacement. LVC should be used for redistributive purposes to redress disadvantage as the benefits of urban land ownership should flow to all city dwellers [65]. Smolka [22] argued that LVC should be used to mobilize some of the land value increments generated by actions other than those of the landowner for the benefit of the community at large. Such actions may include changes in land-use norms and regulations such as rezoning and densification $[22,64,66]$. LVC is seen as an efficient and equitable tool because those who did not contribute to the increased land values do not retain all the financial benefits [67]. Kenya, just like the other Sub-Saharan African countries, faces enormous challenges in providing adequate affordable housing for the increasing numbers of the urban poor, and hence cannot afford to let go the opportunity to apply LVC [68].

In slum regeneration, LVC could best be implemented through inclusionary housing (IH). $\mathrm{IH}$ includes land-use regulations that require developers of market-rate residential developments to make a portion of their units available at prices or rents that are affordable to households unable to afford housing in the market $[23,24]$. Therefore, in our case, developers would be required to set aside a portion of their units for the slum dwellers, the proportion being determined through economic and residual land-value analyses. IH is a means of using the planning system to create affordable housing by capturing resources created by the marketplace [25]. It is a means of harnessing increased land values to finance the development of affordable housing [24] and is a great tool that governments can use to increase affordable housing for low-income urban residents, particularly in prime accessible neighbourhoods.

The use of LVC and IH in slum regeneration has not been fully explored in the literature. This may be because of the way slums are construed-as entities separate from the city, thus propagating exclusion of the 'slum land', 'slum-dwellers', and 'slumlords' from the land and housing market. This is a market segment that is often ignored because it is mostly perceived as highly risky and hence unviable. However, given the prime location of most slums and the high population of low-income earners in our cities chasing the few residential units available for this market segment, there is a huge business opportunity for investors and developers. However, debate on the potential of using LVC for affordable housing in slums is now gaining momentum. Enrique Silva, associate director of the Lincoln Institute's programme on Latin America and the Caribbean, while discussing the challenges presented by slums and informal settlements and the role of land in Will [69] (p.1), observed that "land-based financing tools like property tax or land value capture are not silver bullets, but they certainly play a role in ensuring that land is available for housing and services, thereby improving quality of life. Land-based financing tools, when used correctly and widely, ensure that the costs and benefits of urbanization for all residents are distributed and born as equitably as possible". But governments have not considered the great opportunities presented by land value capture due to failures in strategy and limitations in land tenure and urban planning [3,70].

The idea of involving the private sector in slum areas is not entirely new. El-hadj et al. [3] identified two interesting examples of private-sector involvement in slum upgrading in Africa. The first example is Entreprises de Construction et Aménagement Divers (ECAD) in Kigali, Rwanda. ECAD's approach involved buying rundown, owner-occupied, or rental housing structures in a slum; repairing and refurbishing them; and then selling or renting them at a profit, with an expectation of progressively upgrading the quality of housing in the slum. For example, ECAD would buy a housing structure from a low-income owner for RF 8 million (about USD 11,500), repair and refurbish it, and then sell it to a 
middle-income buyer at RF 15 million (USD 26,582). The second example El-hadj et al. gave is the Trust for Urban Housing Finance (TUHF) Limited in South Africa, which provides loans to entrepreneurs willing to invest in rental accommodation in inner cities. For instance, TUHF can provide financing to renovate rundown buildings or transform old factory buildings into rental accommodation.

The problem with the approaches in the above examples is the possibility of gentrification and displacement of the slum dwellers because of their inability to pay the higher rents. These approaches are unable to provide housing that is fully affordable to poor low-income households, who as a result prefer to leave. However, the failure of land and housing markets to supply affordable housing alternatives for middle-income urban households should also be blamed for the gentrification that occurs when these middle-income households displace low-income and slum households from the upgraded neighbourhoods [3]. An approach is therefore needed that will serve the housing needs of both the low-income slum dwellers and middle-income earners. The approach of LVC through IH will serve this need as it supports the inclusion and integration of different income groups. The approach is seen as supporting the "Right to the City" included in the United Nations Rights to Housing [59], which seeks to promote equal access to the potential benefits of the city for all urban dwellers. However, as El-hadj et al. [3] argued, the private sector faces a number of challenges while working in low-income areas, including serious constraints related to the legal and regulatory framework. But, as Baker and McClain [13] observed, there are opportunities for both the private-sector and slum dwellers to benefit from the engagement of private entities.

El-hadj et al. [3] further argued that despite the inherent informality in slums, private-sector companies can be involved in slum upgrading through the provision of basic infrastructure and services. Where slum upgrading interventions are to be implemented in unattractive, remote, or very poor areas, El-hadj et al. proposed that governments can finance the capital cost of the services and then transfer responsibility for operation and maintenance to private companies. El-hadj et al. further proposed that in some cases, especially for water provision, the government can offer subsidies to private companies to serve upgraded areas. The latter two proposals by El-hadj et al. will face challenges in many developing countries because governments are grappling with dwindling financial resources.

Other approaches including the creation of transferable development rights (TDRs) have been used elsewhere to woo private developers into the low-income market. Vinit [71] gave an example of Mumbai where developers were offered an increase in the permitted floor space index (FSI) if they agreed to produce a given number of low-income units. In cases of slums, Vinit stated that upon densification, the government would require the developer to provide serviced housing in situ for all slum households and allow the developer to use any remaining FSI in developing market-rate units on-site, transfer the FSI as TDRs to another location, or sell them to another developer for use elsewhere in the city. As Baker and McClain [13] observed, developers as business people responded not to the opportunity to upgrade slums or produce low-income housing, but to the opportunity to pursue more high-income development. In this case, it can rightly be argued that the end justified the means.

The potential for LVC in Nairobi presents itself in the following four main fronts: (i) slums on prime public land, (ii) prime public land near the Central Business District (CBD) with very old developments that need urgent renewal/redevelopment, (iii) slums and informal settlements on private land, and (iv) private land with developments that are below the highest and best use. Capturing land value for each category of land identified above will need a different strategy. However, in this case study, we evaluate the application of LVC on slums on prime public land. The housing crisis we are facing calls for a critical assessment of the systems that have existed and aggravated an already bad situation. The city authorities and the national government need to evaluate the role of public land that is mostly invaded by squatters who develop informal settlements that eventually degenerate into slums. The government's ability to combat slums and increase affordable housing hinges on its influence on the use and ownership of its land. Conversion of public land to either community or private land with stringent conditions, including prioritising affordable housing development, can be an important part of a broader response to our slums and affordable housing problem. As land for 
developing affordable housing becomes scarce, government land occupied by slums remains highly ignored, yet most of it is close to the city centre and hence is highly accessible. This land where the urban poor live remains unserved and excluded, constraining development to its highest and best use. Yet the city continues to struggle with the dual challenges of housing its low- and middle-income households and eliminating slums.

There is no doubt, as Graham [72] observed, that land management (allocation, tenure, and use) is fundamental to solving the problems of informal settlements. Graham added that a better managed and equitable land and housing administration system that benefits the poor and increases affordable housing ensures that (i) residents benefit, (ii) chances of gentrification are reduced, (iii) business investment is encouraged to create employment within the community, (iv) mixed-income development is encouraged, and (v) essential urban services are provided.

In designing a working LVC model for affordable housing provision, it is important to understand key requirements for successful implementation of LVC. Agyemang and Morrison [68] identified the key factors required for effective delivery of affordable housing through land value capture. These are summarized and emphasized in Table 1 below.

Taylor [73] also outlined the following key considerations when implementing land value capture schemes, which we have summarised in Table 2 below.

Table 1. Key factors required for effective delivery of affordable housing through land value capture.

\begin{tabular}{|c|c|}
\hline Governance and Planning System & Land and Residential Housing Market \\
\hline $\begin{array}{l}\text { Development rights are owned and controlled by } \\
\text { the State }\end{array}$ & $\begin{array}{l}\text { Clearly delineated, formalised land market and } \\
\text { ownership structure }\end{array}$ \\
\hline $\begin{array}{l}\text { Government commitment to legislative change where } \\
\text { and when necessary to support land value capture }\end{array}$ & $\begin{array}{l}\text { Abundance of formal market players and willingness } \\
\text { to bring forward land by those who hold it }\end{array}$ \\
\hline $\begin{array}{l}\text { Strong enforcement of development control } \\
\text { regulations by city authorities }\end{array}$ & $\begin{array}{c}\text { Strong land and housing market } \\
\text { conditions-economic viability not adversely affected }\end{array}$ \\
\hline $\begin{array}{l}\text { Strong capacity of local authorities-to plan and } \\
\text { undertake residual land value analyses }\end{array}$ & $\begin{array}{l}\text { Strong and experienced private residential } \\
\text { development sector }\end{array}$ \\
\hline $\begin{array}{l}\text { Strong negotiating skills by national government and } \\
\text { city authorities }\end{array}$ & Developer willingness to pay \\
\hline
\end{tabular}

Source: Author's modification from Agyemang and Morrison [68].

Table 2. Key considerations when implementing land value capture.

\begin{tabular}{|c|c|}
\hline Consideration & Rationale \\
\hline Justification & $\begin{array}{l}\text { The government must have increased the value of land through a public } \\
\text { policy or action, and the community is entitled to a share of the resulting } \\
\text { land value uplift. }\end{array}$ \\
\hline Entitlement & $\begin{array}{l}\text { The government must identify the unearned land value uplift resulting } \\
\text { from such public policy or action to decide on the public's legitimate claim } \\
\text { to a share of it. }\end{array}$ \\
\hline Calculation & $\begin{array}{l}\text { How the land value increase will be calculated for value capture purposes } \\
\text { must be clear, and mostly residual land value analyses should be used. }\end{array}$ \\
\hline Development feasibility & $\begin{array}{l}\text { The implementation of value capture should not adversely impact on } \\
\text { development feasibility by denying the developer a reasonable share of } \\
\text { development profit. }\end{array}$ \\
\hline Timing & $\begin{array}{l}\text { In consideration of reasonableness and equity, the value capture } \\
\text { requirement should apply after a nominated date related to the } \\
\text { implementation of the public policy or action }\end{array}$ \\
\hline
\end{tabular}

Source: Author's construction summarised from Taylor [73]. 


\section{Research Methodology}

The research methodology applied in this study was based on a single case study, the slum of Kibera in Nairobi, Kenya. The case study was chosen because Kibera is the largest slum in Kenya and second largest in Africa [18] and is particularly dense, thus making regeneration attempts challenging. The Kibera slum is very conveniently located near the Central Business District (CBD) of Nairobi and posh residential estates, hence it benefits from being positioned in a high value location in real estate market terms. The research methodology was developed by testing the hypothesis that the real estate market in Nairobi would be sufficient to support the production of affordable housing to meet the needs of slum residents, through a hypothetical spatial master plan and related economic and residual land value analyses applied thereon. It was envisioned that the master plan would incorporate principles of sustainable urban planning, i.e., mixed-use; respectful of the social context and identity; with a high quality of public spaces and walkability. It would consider as a canvas for the new development the existing socioeconomic fabric (existing small retail economic activities and villages) in order to meet not only financial sustainability goals but also the wider sustainable planning concept. The reconfiguration of the slum's physical fabric should be grounded in the existing socioeconomic and physical conditions, assuming that local identity and social ties are embedded in the current physical fabric. Hence, streets were reorganised but not changed, keeping in place the same economic pattern and distribution of services. In the model, the envisioned master plan and the residual land value analyses accommodated all residents and retailers, resulting in no eviction or relocation. As Assefa and Peter [21] observed, a positive and sustainable slum upgrading and regeneration should not solely provide affordable housing and infrastructure but should prioritize economic, social, and community activities that are needed to turn around downward trends in a slum area. Assefa and Peter emphasized that such an approach can indeed lead to urban regeneration at a precinct level and impact the overall urban fabrics of cities. The methodology proposed incorporated the UN-Habitat Participatory Upgrading approach [74] as it involved the participation of the local community (slumlords and tenants), relevant stakeholders, developers, and the government to form a strong network focussed on seeking a sustainable financial solution to the slum problem. The methodology was also motivated by the World Bank's urban strategy, which promotes "an approach that facilitates spatial efficiency in production while addressing concerns of congestion and internal divisions within urban areas" while focussing on "harnessing urbanization to deliver equitable and inclusive growth and poverty alleviation" [12] (p.5).

The legal context in Kenya was analysed through a systematic review of the current laws related to land use and land administration in order to understand their provisions (whether they support or curtail land value capture). These statutes included the Constitution of Kenya 2010 [75], the Physical and Land Use Planning Act of 2019 [76], the Land Act No. 6 of 2012 [77], the Land Registration Act No. 3 of 2012 [78], the National Land Commission Act No. 5 of 2012 [79], the Community Land Act No. 27 of 2016 [80], and the Urban Areas and Cities Act No. 13 of 2011 [81].

The researchers analysed current plans, financial data, reports and documents on the spatial planning process, and slum regeneration strategies in Nairobi. The researchers considered the existing social fabric, which is embedded in the physical fabric of the Kibera villages. Each village holds a specific social identity, mainly related to the tribal social structure, and is politically managed by a local leader, the chief. Hence, the spatial plan was proposed for a chosen village rather than for the entire Kibera, assuming that the methodology could easily be upscaled to the entire slum but recognizing that the phasing-up of the regeneration strategy should be approached on a village-by-village basis. Soweto East was selected as the sub-case for the research due to its proximity to an existing area of recent regeneration. This selection was also motivated by the availability of reliable benchmark data for the economic calculations. Residual land value analyses were conducted simultaneously to verify the hypothesis financially. Informal consultations with Stefano Marras, a sociologist with previous experience in mapping Kibera, in a participatory approach allowed taking into account social considerations both in setting up the methodology for approaching the spatial plan, and in understanding the context and its peculiarities. 
Data collection was carried out over a 12-month period from May 2019 to April 2020. Secondary data were gathered from the city offices and websites while primary data were gathered through interviews, complemented by surveys and field observations. In testing the applicability of the proposed model, the author interviewed city and national government officials, academics (experts in planning, law, and real estate), private practising professionals, community leaders, as well as developers. These persons were purposively selected from the Nairobi city planning office; the Kenya Slum Upgrading Programme; the Ministry of Transport, Infrastructure, Housing, Urban Development and Public Works; the Ministry of Lands and Physical Planning; the National Land Commission; the University of Nairobi and civil society groups operating in Kibera. Other stakeholders were purposively selected from among the many actors operating in Kibera. Informal discussions with the local administration (chief), residents, and academics provided leads on who were the main stakeholders to contact. The primary data collected from the Kenya Slum Upgrading Programme (KENSUP) and government ministry officials were related to issues in the existing programme, including implementation and challenges encountered. Developers were interviewed regarding their willingness to participate in the proposed programme. Academics and community leaders provided views on how they perceived the proposal and how to make the model succeed in Kibera, the former based on their experiences in researching in Kibera, and the latter based on their knowledge of community needs within Kibera.

Interviews were complemented by a survey undertaken among slum dwellers (slumlords and tenants). Their selection was undertaken through cluster, stratified, and simple random sampling techniques to ensure representation of the population. The clusters were based on the locations of the structures they owned or leased within the slum, while the stratification was based on type of occupant-whether slumlord (structure owner) or tenant, hence two stratums. A grid was prepared covering the whole study area (Soweto East village, zones $C$ and D) and then samples of structures were picked in each grid through simple random sampling. A total of 97 structures were identified, and subsequently the household heads of at least two units (structure owner and one tenant or two tenants where the structure owner was absent) were approached and served with the questionnaires. Therefore, a total of 194 questionnaires were served. Of these, 156 questionnaires (80.4\%) were returned. Demonstrations of residual land value analyses were simultaneously undertaken with a follow-up survey among slumlords and follow-up interviews with developers. Table 3 below shows the composition of those interviewed, while Table 4 shows the composition of Kibera residents surveyed.

Residents were asked questions regarding their demographic and household characteristics (including number and ages of children, household size, and rent payable), their own assessment of the ongoing Kibera upgrading project, and their views on the proposed model of affordable housing provision. Field observation was also undertaken during repeated fieldwork sessions. Finally, based on the data collected, a hypothetical master plan and housing prototypes for zones $C$ and $D$ were envisioned. These prototypes were subjected to residual land value analyses to test their feasibility and to determine the most feasible scenarios for development within the slum with land value captured through inclusionary housing. In validating the model, discussions were held with two experts from the University of Nairobi and one expert from the UN-Habitat's participatory slum upgrading programme (PSUP). For these discussions, two meetings were held with the University of Nairobi experts and four meetings with the UN-Habitat expert. 
Table 3. Composition of the expert and stakeholder interviewees.

\begin{tabular}{|c|c|c|c|c|}
\hline Interviewees & Working Sector & Number & Sub Total & Percentage \\
\hline \multicolumn{5}{|l|}{ 1. Professionals/Experts } \\
\hline \multirow{3}{*}{ Planners } & Academia & 1 & \multirow{3}{*}{4} & \multirow{3}{*}{$13.33 \%$} \\
\hline & Public sector & 2 & & \\
\hline & Private Sector & 1 & & \\
\hline \multirow{3}{*}{ Land Economists/valuers } & Academia & 1 & \multirow{3}{*}{4} & \multirow{3}{*}{$13.33 \%$} \\
\hline & Public sector & 1 & & \\
\hline & Private Sector & 2 & & \\
\hline Land Economists/Building surveyors & Public sector & 3 & 3 & $10.00 \%$ \\
\hline \multirow{2}{*}{ Lawyers } & Public sector & 1 & \multirow{2}{*}{2} & \multirow{2}{*}{$6.67 \%$} \\
\hline & Private Sector & 1 & & \\
\hline Housing planners & Public sector & 2 & 2 & $6.67 \%$ \\
\hline \multirow{2}{*}{ Architects } & Public sector & 1 & \multirow{2}{*}{2} & \multirow{2}{*}{$6.67 \%$} \\
\hline & Private Sector & 1 & & \\
\hline Land administrators & Public sector & 2 & 2 & $6.67 \%$ \\
\hline Estate Agents & Private Sector & 2 & 2 & $6.67 \%$ \\
\hline \multicolumn{5}{|l|}{ 2. Other Stakeholders } \\
\hline \multicolumn{2}{|c|}{ Community leaders in Kibera } & 2 & 2 & $6.67 \%$ \\
\hline \multicolumn{2}{|c|}{ Civil society members operating in Kibera } & 2 & 2 & $6.67 \%$ \\
\hline \multicolumn{2}{|l|}{ Private developers } & 5 & 5 & $16.65 \%$ \\
\hline \multicolumn{3}{|c|}{ TOTAL } & 30 & $100 \%$ \\
\hline
\end{tabular}

Source: Author's construction; February 2020.

Table 4. Composition of the Kibera survey respondents.

\begin{tabular}{cccc}
\hline & Strata & Number & Percentage \\
\hline \multirow{2}{*}{ Kibera Respondents } & Tenants & 142 & $91 \%$ \\
\cline { 2 - 4 } & \multicolumn{1}{c}{ Slumlords/Structure owners } & 14 & $9 \%$ \\
\hline & TOTAL & 156 & $100 \%$ \\
\hline
\end{tabular}

Source: Author's construction; February 2020.

\section{Setting the Context for the Case Study}

\subsection{The City of Nairobi}

Nairobi is the capital city of Kenya and lies at the southern end of Kenya's agricultural heartland, $1.19^{\circ}$ south of the equator and $36.59^{\circ}$ east of meridian 70 . Its altitude varies between 1600 and $1850 \mathrm{~m}$ above sea level [82]. The city is located about $486 \mathrm{~km}$ by road from Mombasa, Kenya's second largest city located on the shores of the Indian Ocean and about $344 \mathrm{~km}$ by road from Kisumu, the third largest city, located on the shores of Lake Victoria. It lies adjacent to the eastern edge of the Rift Valley while the Ngong hills occupy the western part of the city. Mount Kenya is located to the north, while Mount Kilimanjaro lies southeast of the city.

\subsection{Demographics Characteristics}

Nairobi is a culturally diverse and cosmopolitan city whose three main population components are Africans (95\%), Asians (about 4\%), and Europeans (about 1\%). All the major Kenyan African ethnic 
groups are represented in the city [83]. Table 5 below shows the population and gender distribution in Nairobi City.

Table 5. Population and gender distribution in Nairobi City.

\begin{tabular}{cccccc}
\hline Area (Sq. Km) & $\begin{array}{c}\text { Population } \\
\text { (August 2019) }\end{array}$ & $\begin{array}{c}\text { Population Density } \\
\text { (No. per Sq. Km) (August 2019) }\end{array}$ & $\begin{array}{c}\text { Number of } \\
\text { Households }\end{array}$ & \multicolumn{2}{c}{ Gender Distribution } \\
\cline { 4 - 6 } & $4,337,080$ & 6247 & $1,506,888$ & $49.9 \%$ & Men \\
\hline 703.9 & Source: Compiled by authors in January 2020; Data from the Kenya National Bureau of Statistics [84].
\end{tabular}

\subsection{Nairobi's Property Market}

The property market in Nairobi and Kenya in general remains robust. According to Cytonn [53], the real estate sector has remained attractive as a result of (i) relatively high returns, which in 2018 averaged at $24.3 \%$ over the previous five years, compared to an average of $13.2 \%$ for traditional asset classes; (ii) continued growth, with the real estate sector contribution to Kenya's GDP increasing to 6.8\% in Quarter 1 of 2018 from the 6.1\% recorded in Quarter 1 of 2017, according to data from the Kenya National Bureau of Statistics (KNBS); and (iii) low supply in the residential sector, which has a housing deficit of 2 million units.

According to Department for International Development (DFID) [85], the current land and housing administration legislations and procedures in Kenya are inappropriate for poor people who live in the rapidly growing urban centres. DFID further observed that the urban poor have been unable to comply with these existing planning standards, regulations, and administrative systems since the regulatory framework is complex, and compliance often involves long administrative procedures with long delays. The result has been the proliferation of slums and informal settlements across the city where a majority of the city's residents live under poor living conditions, lacking basic services and security of tenure. Slums in Nairobi are mostly located in prime public or private land near the city centre, industrial area, and affluent estates where the slum dwellers access employment opportunities.

Nairobi currently experiences overwhelming housing demand, particularly in the middle- and low-income categories, although output has favoured the moderate- and high-income markets. This high demand is supported by a stable macroeconomic environment and continued infrastructural improvements. Therefore, private rental investment is lucrative and, as Christine [17] observed, private landlords dominate the housing market in the city with rental accommodation being the main form of housing. Christine further observed that Nairobi has experienced uneven spatial development since the colonial era, creating social exclusion of the urban poor (and residents of informal settlements) through urban design and land-use decisions which cater mostly to the middle- and upper-class citizens, severely limiting the space that is currently available to the urban poor.

\section{Legal Context in Relation to Land Value Capture}

A systematic review of the current laws related to land use and land administration in Kenya, including the Constitution of Kenya 2010 [75], the Physical and Land Use Planning Act of 2019 [76], the Land Act No. 6 of 2012 [77], the Land Registration Act No. 3 of 2012 [78], the National Land Commission Act No. 5 of 2012 [79], the Community Land Act No. 27 of 2016 [80], and the Urban Areas and Cities Act No. 13 of 2011 [81], reveals that the government can use various sections in some of the statutes to plan Kibera and implement land value capture for affordable housing provision within the area. Section 52(1) of the Physical and Land Use Planning Act of 2019 [76] empowers the county government on its own motion or when requested by the national government to declare an area as a special planning area. This declaration can be made if that area has been identified as suitable for intensive and specialized development activity; the development of that area might have significant effect beyond that area's immediate locality; the development of that area raises significant urban design and environmental challenges; or the declaration is meant to guide the implementation of strategic national projects. This declaration, which should be published by notice in the Gazette and in 
at least two newspapers of national circulation, is required to specify the area declared as a special planning area and the nature of the proposed development for which the declaration has been made. This will facilitate development of a special area plan that would guide sustainable and economically feasible physical development through a participatory approach.

The Land Act No. 6 of 2012 [77] Section 12 provides that the National Land Commission may, on behalf of the national or county governments, allocate public land. The commission is allowed to set aside land for investment purposes provided that the investments in the land benefit local communities and their economies. This section further provides that, in an allocation of public land, the commission may impose any terms, covenants, stipulations, and reservations that the commission considers advisable, including on the applicant doing such work and spending such money for permanent improvement of the public land within the period specified by the commission; or paying a consideration for a disposition of the public land. It is provided that public land allocated shall not be sold, disposed of, sub-leased, or subdivided unless it is developed for the purpose for which it was allocated. Where the land allocated is not developed in accordance with the terms and conditions stipulated in the lease, the law provides that such land shall automatically revert back to the national or county government, as the case may be. These provisions under the Land Act No. 6 of 2012 [77] Section 12 make the implementation of inclusionary housing requirements practical.

In assessing the proportion of housing units to be affordable, the commission is supported by the National Land Commission Act No. 5 of 2012 [79] Section 6(2)(c), which gives the commission powers to take any measures it considers necessary to ensure compliance with the principles of land policy set out in Article 60(1) of the Constitution, i.e., equity, efficiency, productivity, and sustainability, among others. The Constitution [75] (Article 67(2)) and the National Land Commission Act [79] Section $5(1)(\mathrm{g})$ give the National Land Commission the mandate to assess taxes on the land and premiums on immovable property in any area designated by law. Urban Areas and Cities Act No. 13 [81] of 2011 gives cities and urban areas the power and mandate to control land use, land subdivision, land development, and zoning. In addition, the country's Constitution [75] protects the right to housing. The Constitution [75] in Chapter 4 under Article 43, sub-article 1(a), states that "Every person has the right to accessible and adequate housing, and to reasonable standards of sanitation". Article 60(1) of the Constitution [75] states that "land in Kenya shall be held, used and managed in a manner that is equitable, efficient, productive and sustainable". The way land is used in Kibera definitely does not meet this article's requirement as access to it is not equitable. Given the prime location of the land, it is neither used efficiently nor productively, with the current one-storey iron sheet structures that allow for accommodation of a few residents in a congested environment. Hence, this scenario is not sustainable. The national and county governments may ride on provisions in the various statutes highlighted above to effectively implement land value capture through inclusionary housing.

\section{The Kibera Slum in the City of Nairobi}

\subsection{General Introduction}

Kibera is one of the largest slums in Africa with an average population of approximately 200,000 people $[86,87]$. Kibera is located approximately $5 \mathrm{~km}$ southwest of Nairobi City centre and stands on $2.5 \mathrm{~km}^{2}$. The slum is divided into 13 villages-Kianda, Soweto West, Raila, Gatwekera, Kisumu Ndogo, Makina, Kicchinjio, Kambi Muru, Mashimoni, Lindi, Laini Saba, Silanga and Soweto East (see Figure 1 below).

Buildings in the Kibera slum are mostly mud-walled and are roofed with corrugated iron sheets [89]. One structure contains several single rooms of approximately $12 \mathrm{ft}$ by $12 \mathrm{ft}$, each occupied by a single household. According to Mutisya and Yarime [15], a household in the slum comprises seven members on average. Approximately $10 \%$ of Kibera residents own some of the structures [34,86], whereas the rest are owned by absentee landlords who reside elsewhere [3]. The structure owners charge a monthly rent of approximately USD 15 for a single room. 


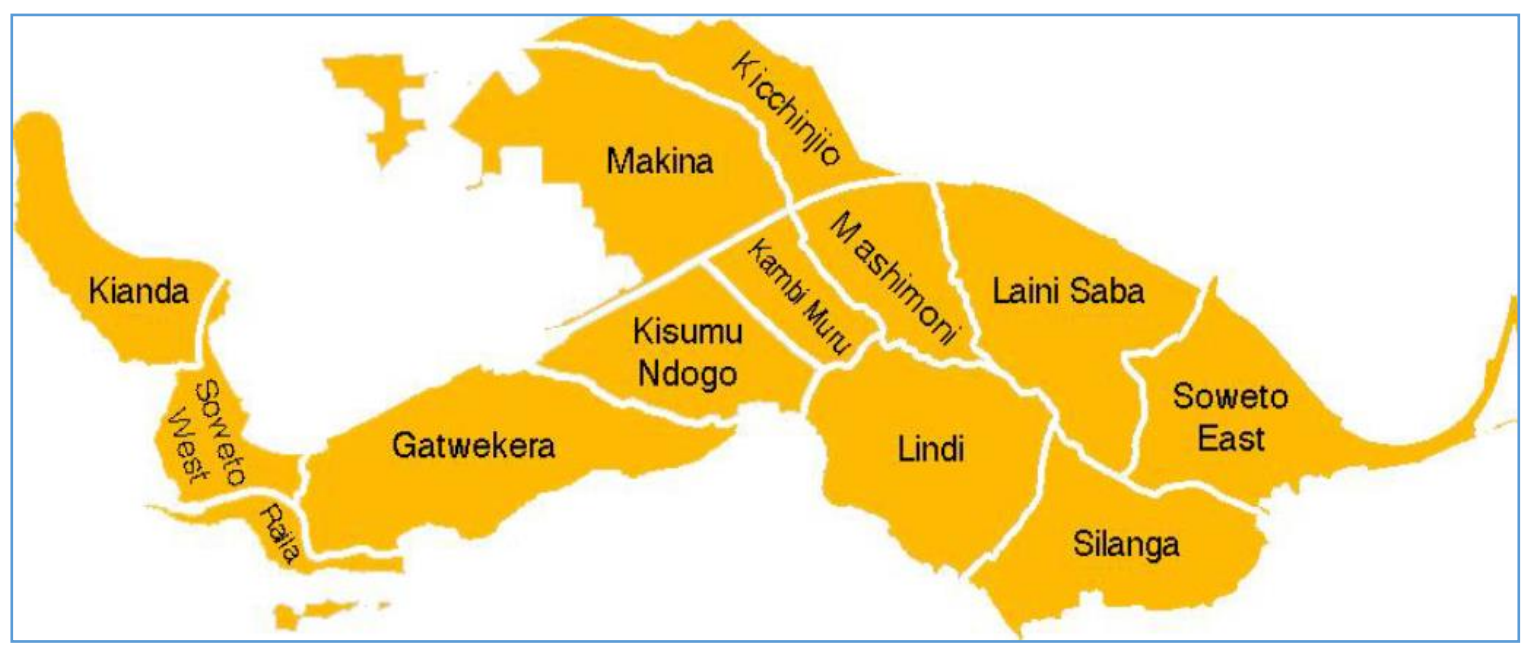

Figure 1. Map showing the 13 villages within the Kibera slum. Source: Map Kibera Project [88].

Most of the residents in Kibera live in abject poverty and rely heavily on their engagement with the city's informal economic sector, particularly buying and selling goods in local markets [17] and within the slum. Others work in either Nairobi's city centre, Nairobi's industrial area, or as domestic servants in Nairobi's affluent estates near Kibera. Because of Kibera's central locality, most residents walk to these places of work.

\subsection{The Kibera Upgrading Initiatives: Progress and Failure}

Through the Kenya Slum Upgrading Programme (KENSUP), the government in partnership with the UN-Habitat, implemented an upgrading pilot project in Soweto East, one of Kibera's 13 villages. To facilitate a systematic implementation process, Soweto East was divided into four zones, namely A, B, C and D [90], with upgrading starting in zone A. Kibera's Soweto East village covers an area of 21.3 hectares and had a population of approximately 19,318 people in $2004 / 2005$, when the project commenced [17,90]. A total of 6377 bona fide residents (household heads) of Kibera Soweto East Zone A were identified to be allocated housing units in the new developments, but the Ministry of Lands through KENSUP committed to build at least 7233 housing units. A decanting site located next to the Lang'ata Women's Prison was built to move and house residents temporarily as the new housing units were being constructed in Kibera Soweto East zone A [90]. A memorandum of understanding between the government and the residents of Kibera Soweto East zone A Village bound the residents to move back to the Soweto East zone A in a tenant purchase scheme once the houses and related infrastructure were ready for occupation. However, within the course of implementation, the project, which had received a lot of global attention and garnered the support of large international agencies, stalled mainly because of the breakdown of partnerships and funding streams [17] and lack of public funds. KNCHR [90] reported that the project only managed to produce 822 housing units in 12 years, leaving a deficit of 6411 units. The project also delivered 245 commercial stalls, a multipurpose centre, and upgraded infrastructure. The housing units are within several seven-storey blocks of flats. Of the 822 housing units, 144 are three-room units, 570 are two-room units, and 108 are one-room units.

As explained earlier, the total land area in Soweto East is 21.3 hectares. Zones C and D occupy 3.6 hectares and 4.5 hectares, respectively $[17,90]$. Our case study area encompasses zones $C$ and $\mathrm{D}-\mathrm{a}$ otal land area of 8.1 hectares.

\section{Possible Solution and Demonstration of the Hypothesis: Assessing the Viability of the Proposed Model for Soweto East, Kibera; Nairobi}

As Cronin and Guthrie [16] observed, one solution for Kibera could be for the government to allow the structure owners to invest in developing the land, in accordance with master planning guidelines 
formulated by the government. Cronin and Guthrie added that it may also be the case that the structure owners are better connected to the community than any NGO or development agency and so have a good understanding of the real needs of their tenants. Interviews with structure owners suggested that some of them can raise funds to put up permanent buildings if approved by the government. They have also developed a bond with their tenants and most of them said it will not be difficult for them to accommodate these tenants in the new developments at a rent that is affordable, if that is the sacrifice they have to make in exchange for secure tenure and higher development rights.

Kibera is congested but the land parcels are not densely developed. The way to address the housing problem in Kibera would be to seize the prime locality of the land and its lack of density and through public policy focus on creating opportunities to build denser and more vertical mixed-use developments. Such a policy should be able to manage the likely possibility of resistance from some structure owners/slumlords, who benefit from rent-seeking within the slum. It should also calm the slum dwellers' fears of losing their affordable homes and eliminate the reluctance of the private developers at getting into the slums. Therefore, the policy must demonstrate to all interested persons that there will be a gain on their side. The model must be designed in a way that it achieves the following: (i) enables the government to economically and sustainably upgrade the slum, (ii) allows slum dwellers to access quality housing at an affordable rent, (iii) fosters social inclusion and curtails gentrification, and (iv) attracts developers and permits them to make a profit despite the provision of subsidized units.

In this research, we offer an alternative and sustainable model of dealing with slums and providing equitable affordable housing. We suggest that a density-focused inclusionary housing development model supported by a well-designed land value capture mechanism might be a useful policy to embrace. Use of land value capture and inclusionary housing will help to eliminate slums, increase affordable housing, and create inclusive and integrated communities. This can be done without displacing the slum dwellers because inclusionary housing ensures that they are accommodated in affordable units provided within the development. This approach will likely result in enough affordable units for the current Kibera residents and future immigrants, thereby achieving two objectives, that is, (i) regenerating the Kibera slum and (ii) preventing development of new slums. As Crawford [91] argued, density incentives, if executed carefully, have the advantage of being more environmentally responsible because they promote less sprawl. The density-sustainability nexus has been widely explored in urban planning theory and practice, and almost unanimous consensus exists on the necessity of managing growth and curbing sprawl. This is consistent with the principle of sustainable land use in Kenya's land policy as set out in Article 60(1) of the Constitution [75]. The approach embraces mixed-use sustainable development and hence anticipates inclusion of small retail and productive activities as well as common public facilities in the master plan. The study demonstrates the financial viability of a real estate market-driven regeneration approach using a village of the Kibera slum, i.e., Soweto East. If adopted, this model can help create a mixture of affordable and market rate housing by tapping the strength of the real estate. This is because, as the model proposes, private developers will be allocated land after planning and then compelled to include affordable units in new developments and contribute an impact fee that will fund (i) temporary relocation costs of the residents and (ii) new infrastructure in the immediate environs to make the neighbourhoods accessible and liveable. The model does not consider only the present population but also includes future low-income residents as well as market rate middle-income residents who will access market properties and trigger the financial viability of the initiative. The model ensures that development requirements simultaneously facilitate infrastructure and new housing development while maximizing affordable housing delivery for the low-income/poor inhabitants. This calls for a delicate balance in the analyses to ensure that both public benefit and project feasibility are achieved. If affordable housing requirements are set too low, the slum would be upgraded, but this will not address the affordability issue and will lead to gentrification. On the other hand, if requirements are set too high, 
no development will occur because it would be financially unfeasible, and thus the slum will not be upgraded and affordable housing will not be provided.

The residual land value analyses represent the financial performances of different prototype developments in the hypothetical master plan area and express how land values will be affected by the proposed increased development density and a range of new requirements, such as affordable housing and development impact fees. These analyses are important in order to find out which development requirements maximise affordable housing provision while achieving development feasibility for the developer.

In order to illustrate the proposed methodological approach in practice, we analysed the subdivision potential and affordable housing requirements for the Soweto East village zones $C$ and D situated in the northeastern part of Kibera, adjacent to Canaan Estate, an existing upgrading project done by the government and UN-Habitat within the Kenya Slum Upgrading Programme framework. Upon collecting the necessary data, we undertook the following steps:

i. Needs assessment: We began by quantifying affordable housing needs in the study area. The affordable housing units required should be equivalent to the current number of households plus an annual increment to take care of a population increase before developments are completed. Our study area lies within the Laini Saba sub-location of Kibera and as per the 2019 Kenya Population and Housing Census, the population density in this area is 81,807 persons per $\mathrm{km}^{2}$ [84]. The total land area for our study area is 8.1 hectares or $0.081 \mathrm{~km}^{2}$, which translates to a population of 6627 persons. Bearing in mind that (i) developments are estimated to take approximately two years and (ii) the annual rate of population increase in Nairobi is 3.9\% [92], the population that needs to be accommodated in affordable housing will have increased to 7168 persons by the time developments are completed. The next step in our user needs assessment was the determination of number of households. Results from the survey conducted showed that the most common household size within the study area is 6 followed by $5,4,3,7,1,8$ and 9 . The average household size was found to be 4.878 , as demonstrated in Table 6 below. The derived average household size was collaborated by other studies. UN-Habitat in Research International [93] reported an average household size of 5 persons, while Amélie and Sophie [87] arrived at an average household size of 3.2 persons. Mutisya and Yarime [15] indicated that a household in Kibera comprises 7 members, although they did not indicate their source or how they arrived at this number. For purposes of determining the number of required affordable housing units for the residents in our study area, this study used the average derived by our analysis but approximated the same at 5 persons per household. The number of affordable housing units was derived by dividing the population in the study area (7168 persons, as determined earlier) by the average household size (5 persons). This resulted in 1434 housing units.

ii. The hypothetical master plan: We proposed a master plan for Soweto East zones C and D (total area of 8.1 hectares). This was done on assumption that the land is rezoned into high-rise flats use. To attain aesthetic value, it was proposed that typical building plans be imposed on all the land parcels save for minor adjustments where the plot areas differ significantly. However, the master plan should strive to achieve uniform plot sizes where possible. It was also proposed that where the building plans are typical, they should be approved in advance by the county government, meaning that developers will not need to make individual applications, hence hastening the development process and reducing the cost. This will act as an incentive to the developers and is important because approval processes have been identified as lengthy and an impediment to the housing development process. In determining the ideal plot sizes, benchmarking was done with other low-income estates in Nairobi, including Umoja, Kayole, and Dandora, to determine the ideal plot size for such a housing scheme. It was determined that land parcels measuring approximately $280 \mathrm{~m}^{2}$ would be ideal for the proposed model. This resulted into 122 land parcels that could be created from the study area. The proposed 
master plan would incorporate two seven-storey prototypes-50 land parcels that front the main arterial routes are proposed to be of mixed use with some commercial units on the ground floor, while 72 land parcels would be purely residential.

iii. Determination of affordable housing requirements per land parcel: Based on the population, household size, and number of households derived in i above, number of land parcels delivered by the master plan in ii above, determination of the affordable housing requirements per land parcel was done as demonstrated in Table 7 below.

iv. Residual Land Value Analyses: Given the developments proposed in the master plan, residual land value analyses for prototype developments were undertaken. Residual land value models are useful in testing feasibility and determining residual values for land subjected to land value capture requirements. The residual values reflect how much private developers would be willing to pay for land in order to meet LVC requirements and achieve development feasibility, taking into account a target rate of return and development risk. Residual land value analyses enable determination of the applicable number of affordable units of different affordability levels to be required, the market units attainable, and the density and the floor area ratio (FAR) to be awarded to enable feasibility of the development. In this stage, the impact of a range of proposed development requirements on the residual land value for each development prototype was modelled.

Table 6. Determination of the average household size in zones C and D, Soweto East, Kibera.

\begin{tabular}{ccc}
\hline Household Size & No. of Households & Total \\
\hline 1 & 3 & 3 \\
\hline 2 & 8 & 16 \\
\hline 3 & 15 & 45 \\
\hline 4 & 33 & 132 \\
\hline 5 & 39 & 195 \\
\hline 6 & 43 & 258 \\
\hline 7 & 10 & 70 \\
\hline 8 & 3 & 24 \\
\hline 9 & 2 & 18 \\
\hline TOTAL & 156 & 761 \\
\hline AVERAGE HOUSEHOLD SIZE & $761 / 156=4.878$ \\
\hline & Source: Author's analysis; April 2020.
\end{tabular}

In implementing this model, the importance of sharing with developers the residual land value analyses cannot be overemphasized. This is because, as Baker and McClain [13] argued, developers are often ill-prepared to service the low-income market, and their lack of experience with poor clients like slum dwellers makes them even more wary of exploring profit-making opportunities in slum areas. Therefore, it was proposed that concurrent with sharing the analyses, the government invite developers to bid for the land with first priority going to the structure owners. Successful bidders would then be allocated the land and granted leases with stringent grant conditions. The first condition or requirement should be payment of a premium to be treated as an impact fee for developing (i) temporary accommodation for the slum dwellers during construction; and (ii) infrastructure such as access roads, walking paths, and pavements within the immediate neighbourhoods. The main arterial infrastructure was already developed under the Kenya Slum Upgrading Programme. In order to protect the funds paid as impact fees, the government needs to dedicate a special account managed by an independent authority who would also monitor compliance with the lease conditions. Secondly, successful bidders would be required to develop affordable housing through 'inclusionary housing' policy, which requires 
the developer to accommodate at the existing or affordable rent the slum dwellers who would be displaced by the upgrading and also include some market-rate units to recoup their investment. In this way, land value would be captured for the common good by ensuring provision of affordable units at no cost to the government. Lastly, it will be important for the developers to be compelled to develop the land within a certain period not exceeding two years. Should any allottee/developer fail to meet the conditions of the grant, the land should revert to the county or national government and be re-allocated as per the provisions of the Land Act No. 6 of 2012 [77] Section 14.

Table 7. Determination of affordable housing units required in zones C and D, Soweto East, Kibera.

\begin{tabular}{|c|c|}
\hline \multicolumn{2}{|l|}{ Determination of Affordable Units Required per Land Parcel/Development } \\
\hline Number of land parcels created by master plan after readjustment and subdivision & 122 \\
\hline \multicolumn{2}{|l|}{$\begin{array}{l}\text { Population of Soweto East zones } C \text { and } D \text { based on the } 2019 \text { Kenya Population and Housing } \\
\text { Census }=0.081 \mathrm{~km}^{2} \times 81,807 \text { persons per } \mathrm{km}^{2}=6627 \text { persons; allowing for population } \\
\text { increase } @ 3.9 \% \text { per annum, population to be housed will be } 7168 \text { persons in } 2 \text { years }\end{array}$} \\
\hline \multicolumn{2}{|l|}{ Average number of persons in a household as per survey analysis $=5$} \\
\hline \multicolumn{2}{|l|}{ Number of households $=7168 / 5=1434$ households } \\
\hline Number of affordable units to be required per land parcel $=1434 / 122=11.75$, i.e., 12 units & 12 \\
\hline \multicolumn{2}{|c|}{$\begin{array}{l}\text { Therefore, development in each land parcel will need to accommodate a minimum of } 12 \text { affordable units if th } \\
\text { proposed model is to be successful. This will result into } 1464 \text { affordable units, enough to cater to the estimated } \\
\qquad 1434 \text { households in zones C and D of Soweto East village, Kibera }\end{array}$} \\
\hline
\end{tabular}

Tables 8 and 9 show the residual land value analyses for the two prototypes for Soweto East zones $C$ and D. Table 8 shows the residual land value analysis of prototype 1 , which is mixed-use. The prototype incorporates a seven-storey plus rooftop development with 43 units (3 shops and 40 residential units). Since most Kibera residents work in the informal sector, provision of shops in some of these developments will be instrumental in supporting livelihoods. Two of the shops are proposed to be availed at affordable rents to Kibera residents and one to be offered at market rent/price. Out of the 40 residential units, 12 units are proposed to be affordable and 28 units are proposed to be market-rate units. Table 9 shows the residual land value analysis of prototype 2 , which is purely residential. The prototype also incorporates a seven-storey plus rooftop development with 42 residential units. Out of the 42 residential units, 12 units are proposed to be affordable and 30 units are proposed be market-rate units. Prototypes 1 and 2 result in $27.9 \%$ and $28.6 \%$, respectively, of the residential units within the prototype developments being affordable and being fully funded by the private developers and hence the market. This also translates into a $27.9 \%$ and $28.6 \%$ inclusivity (mix of different income groups) if inclusion is measured by the proportion of affordable units within upgraded developments. Inclusivity was measured in this way in other studies [94].

To undertake the residual land value analyses shown in Tables 8 and 9, data from various sources were used in order to derive the expected revenues from the finished units and the associated costs of production. To arrive at the market values adopted, we undertook market analyses of sales of similar housing in neighbouring estates, including Kibera Highrise estate, Nairobi dam estate, NHC Langata housing estate, Karanja and Olympic estates. Based on the prevailing rents in Kibera, our analyses indicated that affordable prices/rents would be approximately $25 \%$ to $30 \%$ of the market prices/rents. The housing units for Soweto East zone A under KENSUP were priced at approximately $40 \%$ of the market values [90]. In the analyses, the revenue was deferred for two years to allow for construction and disposal of the units. Costs of production of the units was derived by summing up the following components: (i) costs of construction of the main building, (ii) site works-sewer connection, underground water storage tank, gates, security cameras, etc., (iii) cost of capital-loans used by the developers for construction, (iv) developer's profits- the profit margin expected by the 
developer, (v) development impact fees-these are levied to mitigate the impacts of the proposed development, and (vi) permit approval fees.

Costs of construction were derived from the Institute of Quantity Surveyors of Kenya (IQSK) [95]; the cost of site works was applied at 5.6\% of the cost of the main building as determined by Heather [96]; the current cost of credit in Kenya as applied in the analyses was 13\% [97]. Developers' profit margins in Nairobi can range from $20 \%$ to $40 \%$ [98-100] and hence an average of $30 \%$ was applied in the analyses. Impact fees applied were determined by incorporating two components. The first was the cost of construction for the temporary galvanised corrugated iron sheet structures needed to accommodate the slum dwellers during the development period. These structures will be constructed on public land to be provided by the county government of Nairobi. County officials interviewed expressed support for this proposed model and confirmed that the county government can facilitate the process by availing land for temporary accommodation of the displaced slum dwellers. It was earlier determined that each land parcel would accommodate 12 households. For temporary accommodation, each household was allocated a two-room structure measuring $32 \mathrm{~m}^{2}$. For 12 households, the total built-up area will be $384 \mathrm{~m}^{2}$ and at a construction cost of KES 5000 per m² [95], it will cost Kenya KES 1,920,000 to build the complete structure for the 12 households. For easy appreciation, it is important at this point to indicate that the exchange rates as of 12 June 2020, per the Central Bank of Kenya, were USD $1=$ KES 106.5, GBP 1 = KES 134.9, and EUR 1 = KES 120.9 [101]. This cost (KES 1,920,000) divided by the total built-up area of the proposed development $\left(1293 \mathrm{~m}^{2}\right)$ gives a cost of KES 1500 per $\mathrm{m}^{2}$. The second component of the impact fees covers light infrastructure-access roads and drainage from the main roads to serve the immediate neighbourhood of the land parcels. It is important to note that the main roads have already been tarmacked under KENSUP. Measurements done using GIS on the master plan for such infrastructure within zones $C$ and D resulted in a total area of $7887 \mathrm{~m}^{2}$. At a construction cost of KES 20,000 per $\mathrm{m}^{2}$ [95], the total cost of such infrastructure will be KES 157,746,000. This cost was divided by 122 land parcels to get KES 1,293,000 per land parcel, or KES 1000 per $\mathrm{m}^{2}$ of the main built-up area of the proposed development. Combining the two components resulted in an impact fee of KES 2500 per $\mathrm{m}^{2}$ of the built-up area of the proposed development. Regarding the cost of permit approvals in Nairobi, Keinvest [102] gave the formula for calculating this as supplied by the Nairobi city planning department. Cost of approvals is equal to Joint Building Council (J.B.C.) rate $\times$ plinth area $\times 1.1 \%$. J.B.C. rates vary with the nature of development and for low-cost high-rise flats of 6 floors and above, the rate is KES 24,000 .

The Residual Land Value (RLV) analyses showed that the proposed model of affordable housing provision is feasible, with both prototypes returning positive residual land values. The analyses showed that even with inclusionary requirements imposed, the land parcels would fetch KES 2,943,632/80 for prototype 1 and 5,702,632/80 for prototype 2 if they were offered in the market, with developers making a profit of $30 \%$ on their investments.

It was important to understand how much land value was captured in the model. RLV analyses were developed for the proposed development without land value capture (without inclusionary affordable units). The results of these analyses are shown in Table 10 for prototype 1 and Table 11 for prototype 2 . It is shown in the tables that the residual land value without any value capture would be KES 29,910,632/80 for prototype 1 and KES 28,664,632/80 for prototype 2.

These residual land values in Tables 10 and 11 show how much developers would be willing to pay for the land if inclusionary housing requirements were not imposed. As explained earlier, the residual land values in Tables 8 and 9 indicate how much developers would be willing to pay for the land when inclusionary housing (land value capture) is imposed. Therefore, the value created by the public policy of land alienation to private developers and the subsequent rezoning and master planning can be derived by deducting the residual land values with inclusionary housing from residual land values without inclusionary housing, as shown in Table 12 below. The final results in Table 12 and Figure 2 indicate that the proposed model captures $50.9 \%$ and $53.3 \%$ of the value created under prototype 1 and prototype 2 , respectively. 
Table 8. Residual land value analysis for prototype 1.

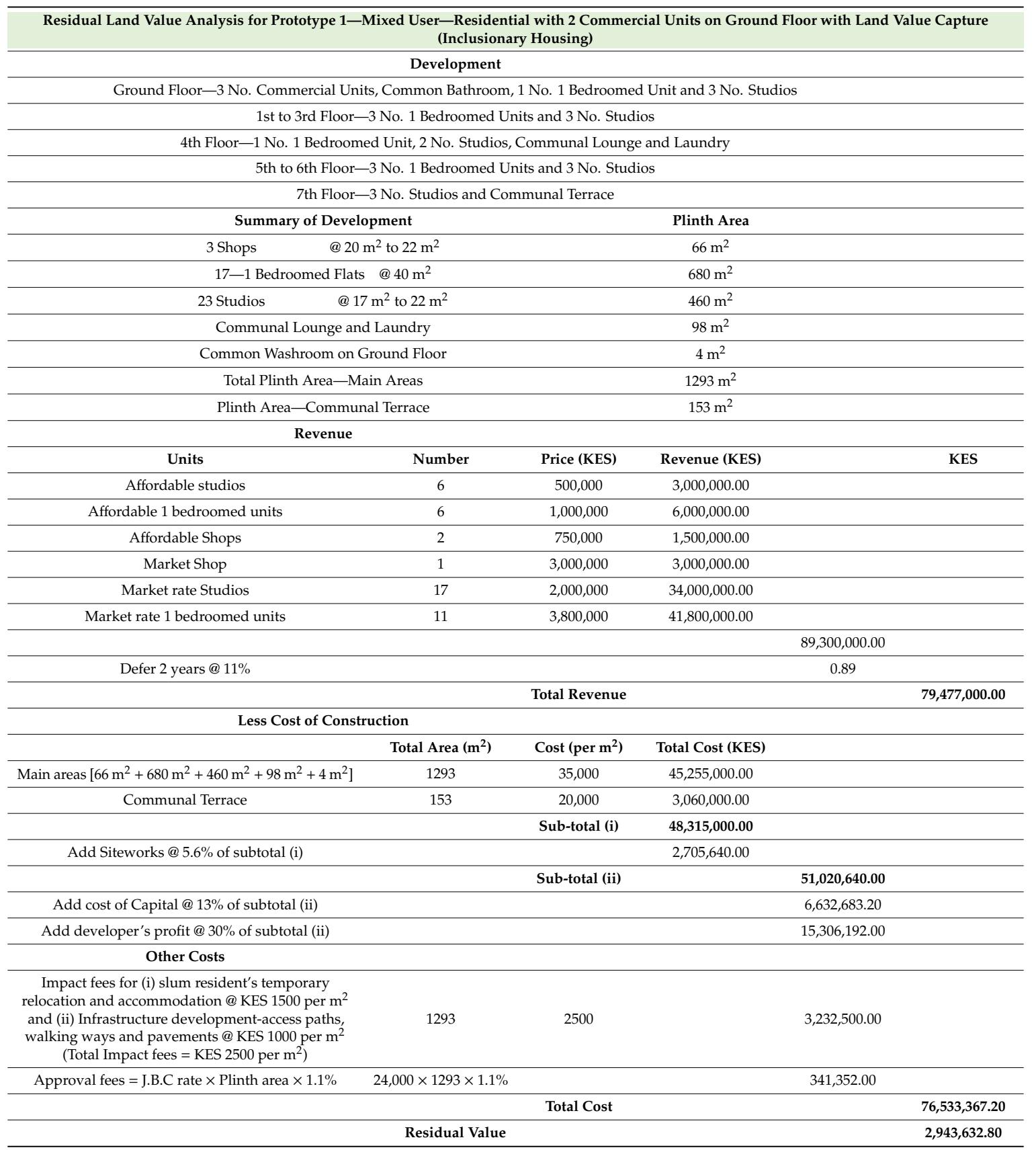

Source: Author's analysis, March-April 2020. Note: KES means Kenya shillings; USD 1 = KES 106.5, GBP 1 = KES 134.9 and EUR 1 = KES 120.9; Source: Central Bank of Kenya [101]. Coloured background is used for emphasis purposes. 
Table 9. Residual land value analysis for prototype 2 .

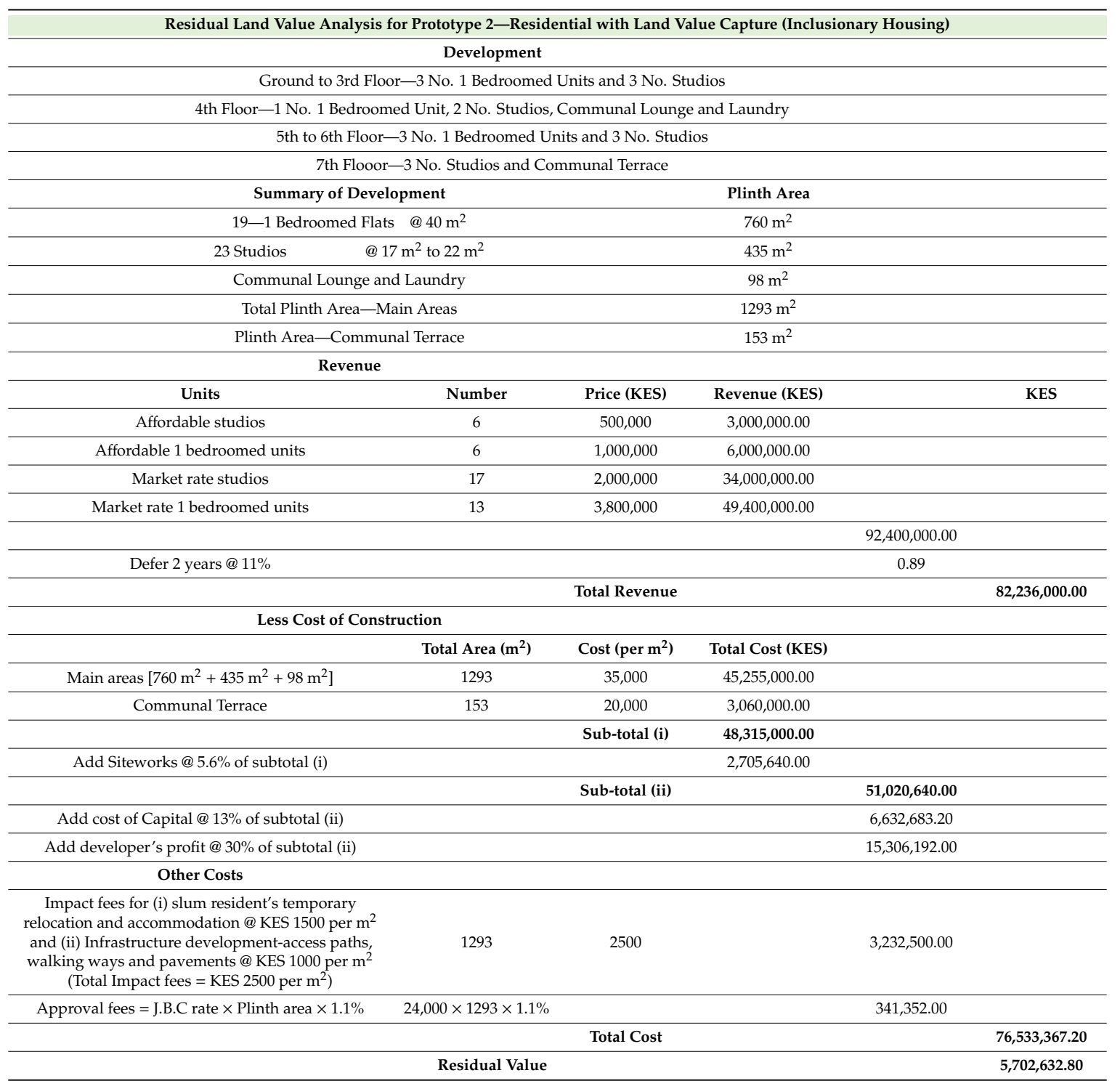

Source: Author's analysis, March-April 2020. Note: KES means Kenya shillings; USD 1 = KES 106.5, GBP 1 = KES 134.9 and EUR 1 = KES 120.9; Source: Central Bank of Kenya [101]. Coloured background is used for emphasis purposes. 
Table 10. Residual land value analysis for a prototype 1 without land value capture.

\begin{tabular}{|c|c|c|c|c|}
\hline \multicolumn{5}{|c|}{ Residual Land Value Analysis for Prototype 1-Mixed User-Residential with 2 Commercial Units on Ground Floor without Land Value Capture } \\
\hline \multicolumn{5}{|c|}{ Development } \\
\hline \multicolumn{5}{|c|}{ Ground Floor-3 No. Commercial Units, Common Bathroom, 1 No. 1 Bedroomed Unit and 3 No. Studios } \\
\hline \multicolumn{5}{|c|}{ 4th Floor-1 No. 1 Bedroomed Unit, 2 No. Studios, Communal Lounge and Laundry } \\
\hline \multicolumn{5}{|c|}{ 5th to 6th Floor-3 No. 1 Bedroomed Units and 3 No. Studios } \\
\hline \multicolumn{5}{|c|}{ 7th Floor-3 No. Studios and Communal Terrace } \\
\hline 3Shops & @ $20 \mathrm{~m}^{2}$ to $22 \mathrm{~m}^{2}$ & \multicolumn{2}{|r|}{$66 \mathrm{~m}^{2}$} & \\
\hline 17-1 Bedroomed Flat & @ $40 \mathrm{~m}^{2}$ & \multicolumn{2}{|r|}{$680 \mathrm{~m}^{2}$} & \\
\hline 23 Studios & @ $17 \mathrm{~m}^{2}$ to $22 \mathrm{~m}^{2}$ & \multicolumn{2}{|r|}{$460 \mathrm{~m}^{2}$} & \\
\hline \multicolumn{2}{|c|}{ Communal Lounge and Laundry } & \multicolumn{2}{|r|}{$98 \mathrm{~m}^{2}$} & \\
\hline \multicolumn{2}{|c|}{ Common Washroom on Ground Floor } & \multicolumn{2}{|r|}{$4 \mathrm{~m}^{2}$} & \\
\hline Units & Number & Price (KES) & Revenue (KES) & KES \\
\hline Market Shops & 3 & $3,000,000$ & $9,000,000.00$ & \\
\hline Market rate studios & 23 & $2,000,000$ & $46,000,000.00$ & \\
\hline \multirow[t]{2}{*}{ Market rate 1 bedroomed units } & 17 & $3,800,000$ & $64,600,000.00$ & \\
\hline & & & \multicolumn{2}{|c|}{$119,600,000.00$} \\
\hline \multirow[t]{2}{*}{ Defer 2 years @ 11\% } & & & \multicolumn{2}{|c|}{0.89} \\
\hline & & \multicolumn{2}{|l|}{ Total Revenue } & $106,444,000.00$ \\
\hline Less Cost of Const & action & & & \\
\hline & Total Area $\left(\mathrm{m}^{2}\right)$ & Cost $\left(\right.$ per $\left.\mathrm{m}^{2}\right)$ & Total Cost (KES) & \\
\hline Add developer's profit @ 30\% of subtotal (ii) & & & & \\
\hline Other Costs & & & & \\
\hline $\begin{array}{l}\text { Impact fees for (i) slum resident's temporary } \\
\text { relocation and accommodation @ KES } 1500 \text { per } \mathrm{m}^{2} \\
\text { and (ii) Infrastructure development-access paths, } \\
\text { walking ways and pavements @ KES } 1000 \text { per m² } \\
\quad\left(\text { Total Impact fees = KES } 2500 \text { per } \mathrm{m}^{2} \text { ) }\right.\end{array}$ & 1293 & 2500 & & \\
\hline Approval fees $=$ J.B.C rate $\times$ Plinth area $\times 1.1 \%$ & $24,000 \times 1293 \times 1.1 \%$ & & & \\
\hline & & Total Cost & & $76,533,367.20$ \\
\hline & Residual Value & & & $29,910,632.80$ \\
\hline
\end{tabular}

Source: Author's analysis, April 2020. Note: KES means Kenya shillings; USD 1 = KES 106.5, GBP 1 = KES 134.9 and EUR 1 = KES 120.9; Source: Central Bank of Kenya [101]. Coloured background is used for emphasis purposes. 
Table 11. Residual land value analysis for a prototype 2 without land value capture.

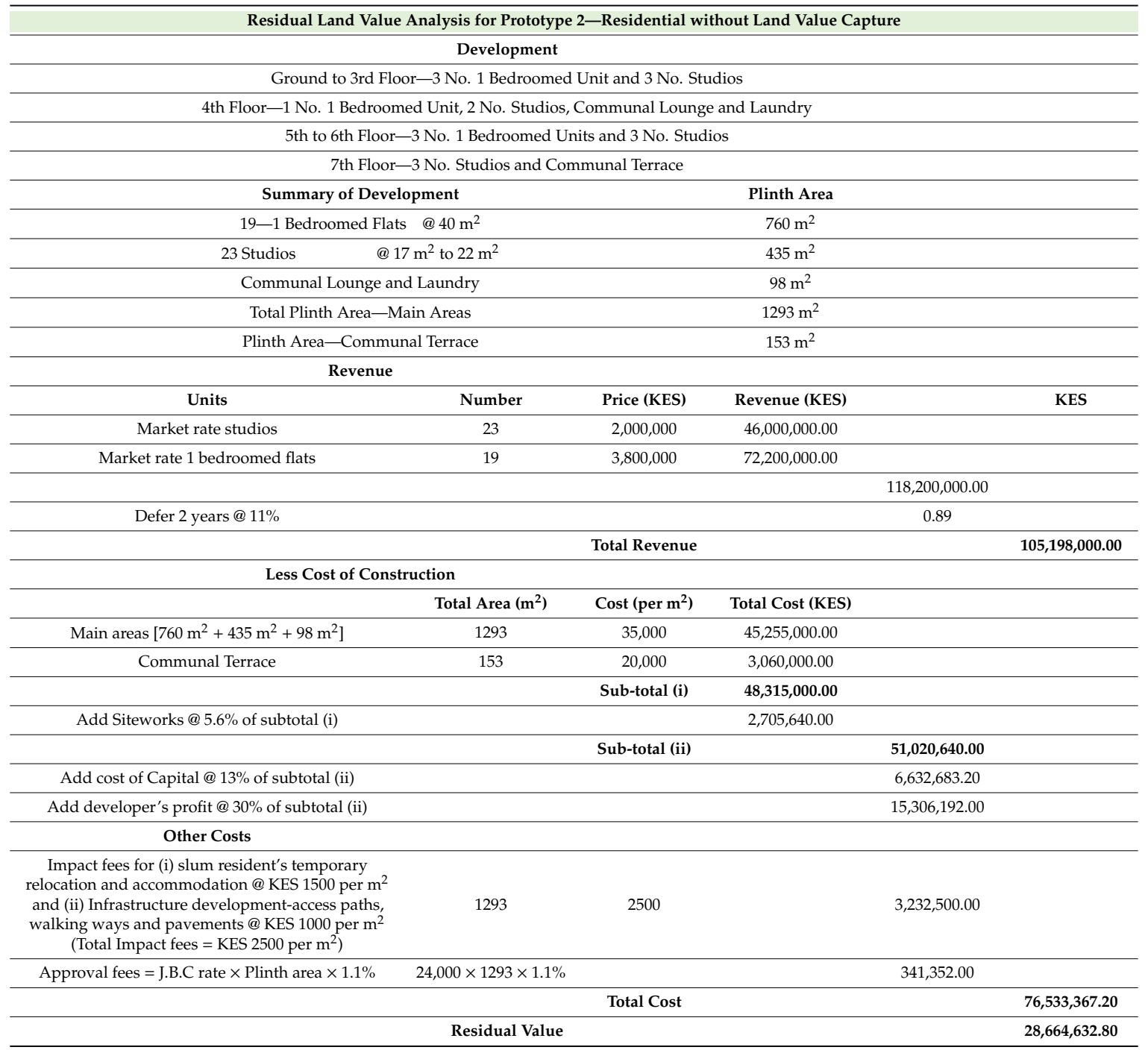

Source: Author's analysis, April, 2020. Note: KES means Kenya shillings; USD 1 = KES 106.5, GBP 1 = KES 134.9 and EUR 1 = KES 120.9; Source: Central Bank of Kenya [101]. Coloured background is used for emphasis purposes. 
Table 12. Determination of the land value captured by the proposed master plan incorporating inclusionary affordable housing in zones C and D of Soweto East, Kibera, Nairobi.

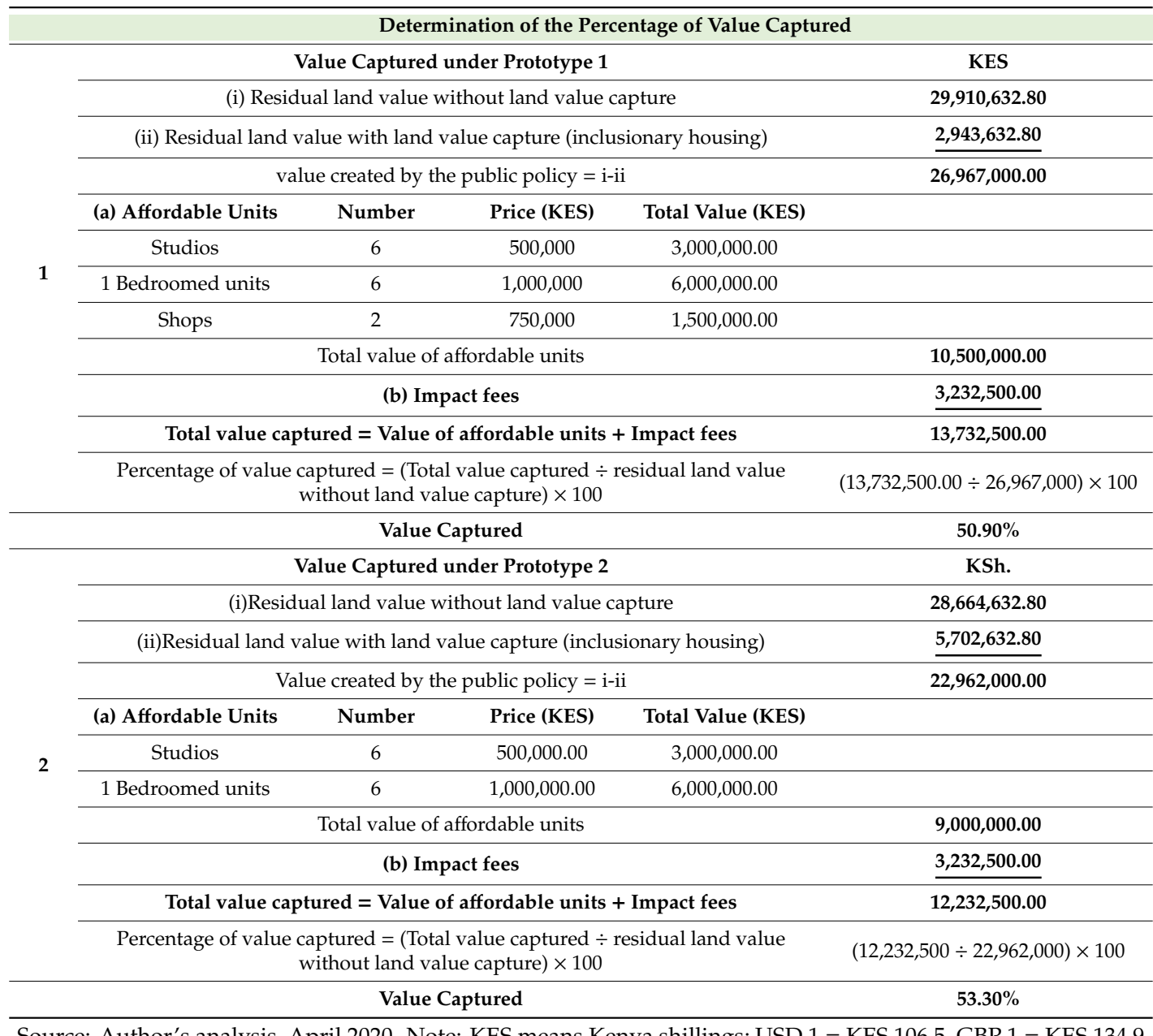

Source: Author's analysis, April 2020. Note: KES means Kenya shillings; USD 1 = KES 106.5, GBP 1 = KES 134.9 and EUR 1 = KES 120.9; Source: Central Bank of Kenya [101]. Coloured background is used for emphasis purposes.

We sought to find out the acceptability of the proposed model among Kibera residents, developers, experts, and government officials. Our survey data shows that Kibera tenant respondents were overwhelmingly supportive of the proposed model, with $92.2 \%$ of them saying they would support it. The structure owners/slumlords were mostly reluctant initially (only $42.8 \%$ supported the approach in the initial survey), whereas after a follow-up survey targeting only the structure owners, which was done with simultaneous demonstration of the RLV analyses, the support among the structure owners/slumlords increased to $85.7 \%$. A total of $25 \%$ of the structure owners who supported the model demanded to be given pre-emptive rights in allocation of the land and indicated that they had the capacity to develop the land in conformity with the proposed master plan. Prior to demonstration of the RLV analyses, $40 \%$ (2 out of the 5) of the developers interviewed indicated they would be willing to participate in the programme. This increased to $80 \%$ (4 out of 5) upon demonstration of the RLV, which showed the model's feasibility. The four developers who supported the model invested mostly in low- and middle-income housing, while the developer who indicated unwillingness to participate in the programme specialised mostly in high-end market properties. The majority of the experts also supported the model, with $90.5 \%$ of them agreeing that the approach would produce more affordable housing and lead to well-integrated neighbourhoods. There was no marked difference in the level of support between experts in the public sector (government officials) and those working in other sectors. Support from government officials was at $90.9 \%$, whereas that from experts in the other sectors was at $90 \%$. One official from Nairobi County offices confirmed that the matter of land value capture has 
been discussed at various senior government forums and the government is very keen on its adoption in order to achieve Vision 2030, although modalities on how and where it can be applied have not been put in place. Figure 3 below shows the level of support for the proposed LVC/IH model among the survey respondents and interviewees.

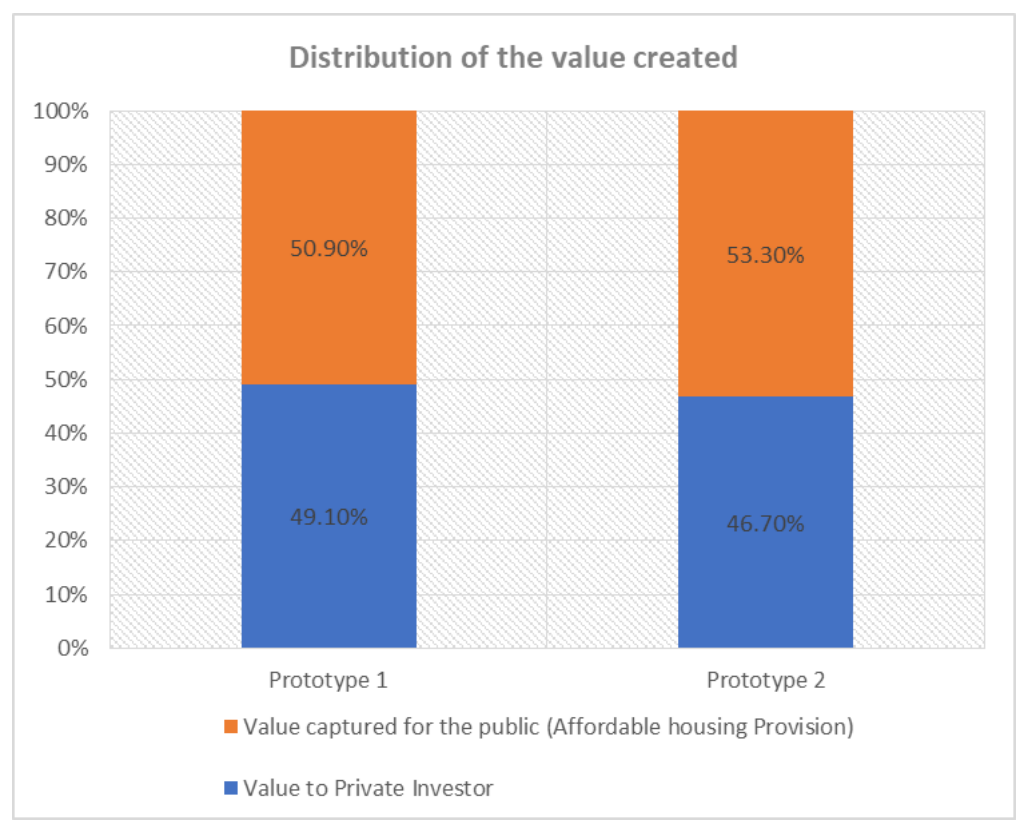

Figure 2. Distribution of the value captured by the proposed master plan incorporating inclusionary affordable housing in zones C and D of Soweto East, Kibera, Nairobi. Source: Author's analysis, April 2020.

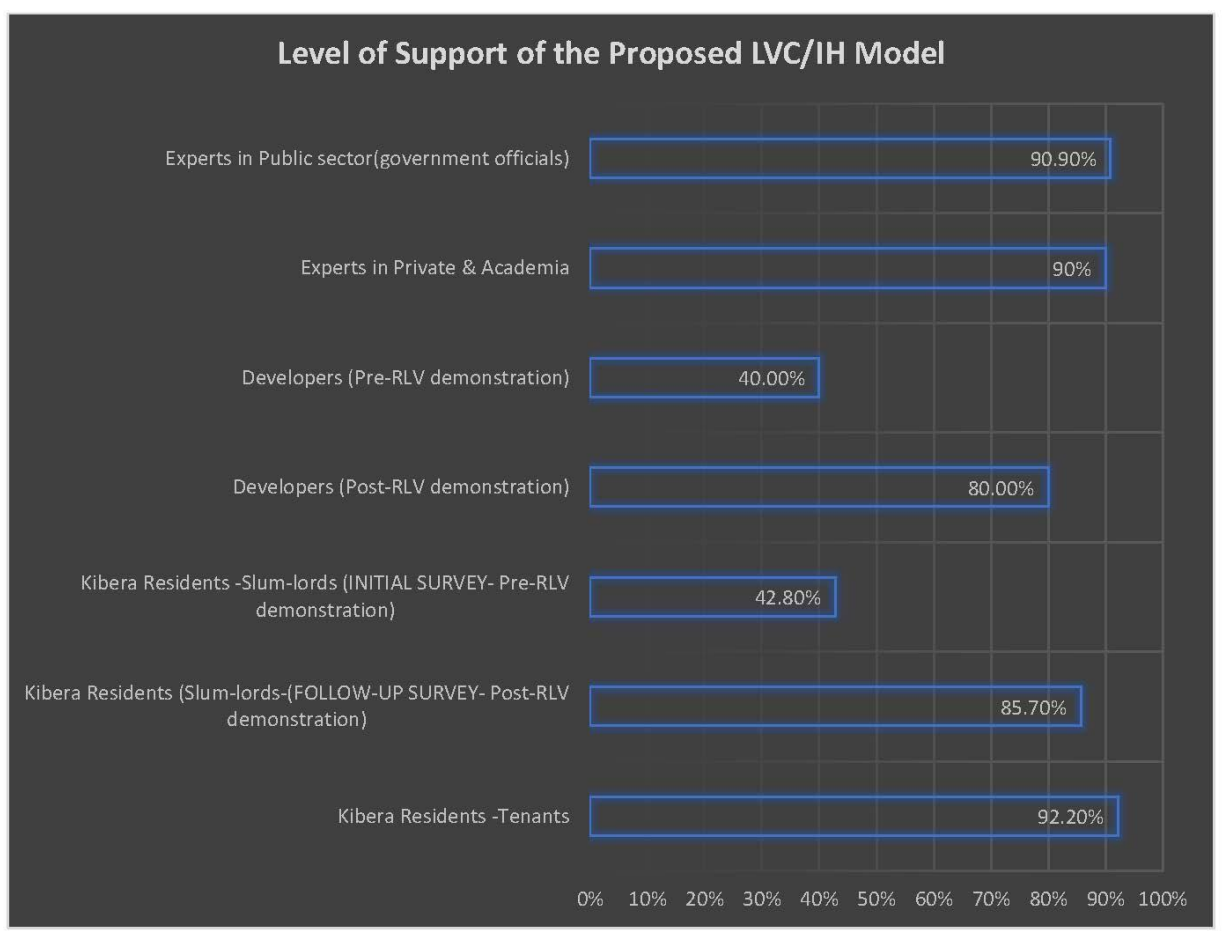

Figure 3. Analysis of the level of support for the proposed LVC/IH model among the survey respondents and interviewees. Source: Authors analysis, June 2020. 


\section{Conclusions}

This study represents an initial attempt to develop a market-driven integrated methodology for slum upgrading based on LVC and IH mechanisms. Literature has shown that tackling the problem of slums and inadequate affordable housing requires new approaches and ideas. From the literature, it is clear that no single effort can be the magical solution to resolve the city's housing needs and, in particular, deal with the slum problem. However, this research suggests that if the country is to overcome the financial limitations it faces in upgrading slums and providing affordable housing, land value capture and inclusionary housing are tools that need to be incorporated in the Kenya Slum Upgrading Programme (KENSUP) and the Affordable Housing Programme (AHP).

This paper contributes to an emerging research agenda, proposing an alternative approach to slum regeneration and affordable housing provision through harnessing the strength of the real estate market. Given the urgent need for new innovative approaches to slum upgrading and considering that the main impediment to successful upgrading has been lack of public funds, the paper proposes the use of land value capture through inclusionary housing policies to meet the housing needs of slum dwellers in the city of Nairobi. This proposal has proved feasible after a thorough analysis of the real estate market in the city and the country's legal framework. This was important because the policy prescription to incorporate LVC and IH or any other tool for slum regeneration "must be based on a grounded understanding of the functioning of markets" [71] (p.792) and the legal framework governing land use in the targeted city.

Through a simulated master plan complemented with economic and residual land value analyses, the paper demonstrates that by availing land to private developers for inclusionary housing development, it is possible to meet slum residents' housing needs by including at least $27.9 \%$ affordable housing in new developments, entirely borne by the private sector. Affordable houses can be delivered at between $25-30 \%$ of the market rents and prices. Private developers would be able to enjoy feasibility of projects because of the enhanced values as a result of land conversion from public to private, planning, infrastructure provision, and the permission for dense developments. The model would lead to well-integrated and inclusive neighbourhoods, and our survey and interview data showed overwhelming support for the proposed model.

The proposed model can be adapted to implement in the entire Kibera slum, with the potential to upscale and adapt for slum regeneration worldwide, provided that specific social and legal aspects are considered. In implementing a similar model in a similar context, there are lessons learnt including the following:

i. The need for a bottom-up approach and engagement with the community at the grassroots level;

ii. The need to use the established social setup and leadership, including area chiefs in negotiating with the community. It is important to involve leaders such as governors, ministers, and local politicians who can lead the process, lobby for political support from senior offices, and initiate legal amendments, if necessary, to facilitate or support the upgrading process;

iii. The need to encourage involvement of stakeholders, including local non-governmental and civil society organizations, county and national government departments, and private entities in the upgrading process;

iv. For large slums like Kibera, this model can best be implemented on an incremental basis, village after village, rather than pursuing an urban layout plan and upgrading the whole slum in a single phase. This will ease the burden of alternative accommodation of the slum dwellers during construction. Also, the project success in the initial phases will trigger increased interest from developers and other participants who initially might have been reluctant in getting involved.

Finally, findings suggest that market forces can be the financial drivers to ending slums by 2050 and can have a high potential to increase both affordable and market housing in upgraded neighbourhoods, hence enhancing social inclusion in cities of developing countries. 
Further studies could contribute to (1) developing an actual master plan for the study area through the recommended bottom-up participatory approach, and (2) developing a framework and model for LVC/IH for (a) prime public land near the CBD with very old developments that need urgent renewal/redevelopment, (b) slums and informal settlements on private land, and (c) private land with developments that are below the highest and best use.

Author Contributions: This paper is based on B.N.'s PhD work. B.N. designed and performed the research, undertook data collection and analyses, and prepared the initial draft. C.T. was the PhD supervisor. C.T. revised the draft. All authors have read and agreed to the published version of the manuscript.

Funding: This research received no external funding.

Acknowledgments: This work would not have been possible without the kind and generous availability of many experts who shared ideas and thoughts essential to the development of this research. We appreciate the officials of various government offices in the city of Nairobi. We thank the academics, community leaders, professionals in the public and private sectors, developers, affordable housing stakeholders, and city residents interviewed for their help. We express our gratitude to the three anonymous reviewers who greatly helped us to improve the quality of the paper. Any possible inaccuracy or omission remain our exclusive responsibility.

Conflicts of Interest: The authors declare no conflict of interest.

\section{References}

1. World Bank. Housing: Unavailable and Unaffordable; Kenya Economic Update. 2017. Available online: http://documents.worldbank.org/curated/en/988191491576935397/pdf/114115-REVISED-PUBLICKenyaEconomicUpdateFINALFINALMay.pdf (accessed on 20 August 2019).

2. UN-Habitat. Financing Urban Shelter: Global Report on Human Settlements 2005. Available online: https://unhabitat.org/sites/default/files/download-manager-files/GRHS2005.pdf (accessed on 23 March 2020).

3. El-hadj, M.B.; Issa, F.; Zekebweliwai, F.G. Housing Market Dynamics in Africa. M Macmillan Publishers Ltd., 2018. Available online: https://link.springer.com/content/pdf/10.1057\%2F978-1-137-59792-2.pdf (accessed on 12 May 2019).

4. Cities Alliance. About Slum Upgrading. 2020. Available online: http://www.citiesalliance.org/About-slumupgrading (accessed on 13 January 2020).

5. Ron, M.; Andrew, C.; Arie, C.; Peggy, A. The study of slums as social and physical constructs: Challenges and emerging research opportunities. Reg. Stud. Reg. Sci. 2016, 3, 399-419. [CrossRef]

6. UN-Habitat. Slum Almanac 2015/2016. Tracking Improvement in the Lives of Slum Dwellers. 2015. Available online: http://unhabitat.org/wp-content/uploads/2016/02-old/Slum\%20Almanac\%202015-2016_EN. pdf (accessed on 24 November 2019).

7. Millington, K.A.; Cleland, J.C. Counting People and Making People Count: Implications of Future Population Change for Sustainable Development. 2017. Available online: https://pdfs.semanticscholar.org/241e/bbb91429cc9940e56e879a17e413bee35286.pdf?_ga=2.109526469. 1996243206.1587850806-1140400251.1569094698 (accessed on 25 November 2019).

8. UN DESA. World Economic and Social Survey: Sustainable Development Challenges; United Nations Department of Economics and Social Affairs: New York, NY, USA, 2013; Available online: www.un.org/en/development/ desa/policy/wess/wess_current/wess2013/WESS2013.pdf (accessed on 10 March 2020).

9. Tito, Y.; Somik, L.V. Evaluating the Impact of Upgrading Informal Settlements on Land Markets: Evidence from Bogotá1. The World Bank. Available online: http://www1.worldbank.org/prem/poverty/ie/dime_ papers/1113.pdf (accessed on 19 January 2020).

10. Perry, N.; Greenhalgh, H.; Cong, M.H.; Liu, H.; Zhang, Y. An Exploration of the Implementation and Sustainability of Urban Area Policies Aimed at Millennium Development Goals \#1 and \#7; Report Prepared for the Division for Public Administration and Development Management (DPADM), United Nations Department of Economic and Social Affairs (UNDESA); USC Sol Price School of Public Policy, University of Southern California: Los Angeles, CA, USA, 2014; Available online: http://workspace.unpan.org/sites/Internet/Documents/ UNPAN93524.pdf (accessed on 24 January 2020).

11. UN-Habitat. Streets as Tools for Urban Transformation in Slums: A Street-Led Approach to Citywide Slum Upgrading; Working Paper; UN-Habitat: Nairobi, Kenya, 2012. 
12. World Bank Systems of Cities: Harnessing Urbanization for Growth \& Poverty Alleviation. The World Bank Urban \& Local Government Strategy. 2010. Available online: Http://Siteresources.Worldbank.Org/ Inturbandevelopment/Resources/336387-1269651121606/FullStrategy.pdf (accessed on 17 January 2020).

13. Baker, J.L.; McClain, K. Private Sector Involvement in Slum Upgrading. Glob. Urban. Dev. Mag. 2008, 4, 1-19.

14. UN-Habitat. Bridging the Affordability Gap: Towards a Financing Mechanism for Slum Upgrading at Scale in Nairobi. 2019. Available online: https://unhabitat.org/sites/default/files/2020/05/financing_mechanism_ for_slum_upgrading_at_scale_in_nairobi.pdf (accessed on 20 January 2020).

15. Mutisya, E.; Yarime, M. Understanding the Grassroots Dynamics of Slums in Nairobi: The Dilemma of Kibera Informal Settlements. Int. Trans. J. Eng. Manag. Appl. Sci. Technol. 2011, 2, 197-213. Available online: http://TuEngr.com/V02/197-213.pdf (accessed on 16 December 2018).

16. Cronin, V.; Guthrie, P. Alternative approaches to slum upgrading in Kibera, Nairobi. Proc. Inst. Civ. Eng. Urban Des. Plan. 2011, 164, 129-139. [CrossRef]

17. Christine, S. Struggling for the 'Right to the City': In Situ Informal Settlement Upgrading in Kibera, Nairobi. Master's Thesis, Faculty of Graduate and Postdoctoral Affairs, Carleton University, Ottawa, ON, Canada, 2015. Available online: https://curve.carleton.ca/d0913f63-6af9-4477-b8ff-3b6d43d22209 (accessed on 26 January 2020).

18. Joseph, M. Urban Slum Morphology and Socio-economic Analogies: A Case Study of Kibera Slum, Nairobi, Kenya. Urbanization 2018, 3, 17-32. [CrossRef]

19. Obare, M.J. An Evaluation of Slum Upgrading Schemes in Nairobi County: The Case of Kibera Slums. Bachelor's Thesis, The School of Environmental Studies, Kenyatta University, Nairobi County, Kenya, 2015.

20. United Nations. About the Sustainable Development Goals. 2015. Available online: https://www.un.org/ sustainabledevelopment/sustainable-development-goals/ (accessed on 18 March 2020).

21. Assefa, T.; Peter, N. Slum Regeneration and Sustainability: Applying the Extended Metabolism Model and the SDGs. Sustainability 2017, 9, 2273. [CrossRef]

22. Smolka, M.O. Implementing Value Capture in Latin America: Policies and Tools for Urban Development; Lincoln Institute of Land Policy: Cambridge, MA, USA, 2013.

23. Calavita, N.; Mallach, A. Inclusionary Housing, Incentives, and Land Value Recapture; Land Lines; Lincoln Institute of Land Policy: Washington, DC, USA, 2009.

24. Schuetz, J.; Meltzer, R.; Been, V. 31 Flavors of Inclusionary Zoning: Comparing Policies from San Francisco, Washington, DC, and Suburban Boston. J. Am. Plan. Assoc. 2009, 75, 441-456. [CrossRef]

25. Calavita, N.; Mallach, A. Inclusionary Housing in International Perspective: Affordable Housing, Social Inclusion, and Land Value Recapture; Lincoln Institute of Land Policy: Washington, DC, USA, 2010.

26. Wyatt, P. Can land value uplift deliver affordable housing? Experiences from England. J. Eur. Real Estate Res. 2018, 11, 87-101. [CrossRef]

27. Corinne, M. Accessibility and Residential Land Value Uplift: Identifying Spatial Variations in the Accessibility Impacts of a Bus Transitway. Urban Stud. 2013, 51, 1707-1724. [CrossRef]

28. Francesca, M. Land value capture finance for transport accessibility: A review. J. Transp. Geogr. 2012, 25, 154-161. [CrossRef]

29. UNECE. Land Value Capture as a Factor of Housing Affordability. 2019. Available online: https:// www.unece.org/fileadmin/DAM/hlm/sessions/docs2019/Info_3_2019_Land_Value_Capture.pdf (accessed on 7 December 2019).

30. Freire, S.P. Achievements and Challenges on Inclusionary Housing and Land Value Capture Instruments in Brazil. 2013. Available online: https://www.researchgate.net/publication/319087923 (accessed on 6 July 2019).

31. UN-Habitat. State of the World's Cities 2006/7. 2006. Available online: https://sustainabledevelopment.un. org/content/documents/11292101_alt.pdf (accessed on 7 December 2019).

32. Sjoberg, G. The Preindustrial City: Past and Present; Free Press: New York, NY, USA, 1960.

33. Meier, J.E. "On the margins": The emergence and growth of informal settlements in the greater Cape Town area, 1939-1960. Ph.D. Thesis, University of Florida, Gainesville, FL, USA, 2000. Available online: https://ufdcimages.uflib.ufl.edu/AA/00/02/65/19/00001/onmarginsemergen00meie.pdf (accessed on 12 December 2019).

34. UN-Habitat. The Challenge of Slums: Global Report on Human Settlements, 2003; Earthscan: Sterling, VA, USA, 2003; pp. 105-106. 
35. UN-Habitat. A Practical Guide to Designing, Planning, and Executing Citywide Slum Upgrading Programmes; UN-Habitat: Nairobi, Kenya, 2014; ISBN 978-92-1-132660-4.

36. Clifford, A.; Brandful, C.P. Slum improvement in the Kumasi metropolis, Ghana-A review of approaches and results. J. Sustain. Dev. Afr. 2011, 13, 8.

37. World Bank. Upgrading Low Income Urban Settlements Country Assessment Report. Accra, 2002. Available online: http://siteresources.worldbank.org/INTUSU/Resources/ghana-assess.pdf (accessed on 22 April 2019).

38. Chiodelli, F.; Moroni, S. The complex nexus between informality and the law: Reconsidering unauthorised settlements in light of the concept of nomotropism. Geoforum 2014, 51, 161-168. [CrossRef]

39. Fekade, W. Deficits of formal urban land management and informal responses under rapid urban growth, an international perspective. Habitat Int. 2000, 24, 127-150. [CrossRef]

40. UN-Habitat. The State of African Cities: A Framework for Addressing Urban Challenges in Africa; UN-Habitat: Nairobi, Kenya, 2008; ISBN 978-92-1-132015-2.

41. UN Habitat. The State of African Cities: Governance, Inequality and Urban Land Markets; UN-Habitat: Nairobi, Kenya, 2010; ISBN 978-92-1-132291-0.

42. Jacobus, R. Inclusionary Housing: Creating and Maintaining Equitable Communities. Lincoln Institute of Land Policy, 2015. Available online: https://www.lincolninst.edu/sites/default/files/pubfiles/inclusionaryhousing-full_0.pdf (accessed on 2 December 2018).

43. James, M.G. An Investigation into the Challenges Facing Implementation of Slum Upgrading Programmes in Kenya: A Case Study of Manyatta, Kisumu County. School of Built Environment. University of Nairobi Unpublished work. ,2012. Available online: http://erepository.uonbi.ac.ke/bitstream/handle/11295/ 90750/Mwangi_An\%20investigation\%20into\%20the\%20challenges\%20facing\%20implementation\%20of \% 20slum\%20upgrading\%20Programmes\%20in\%20Kenya?sequence=3 (accessed on 22 April 2019).

44. Omwoma, M.R. Land Tenure Systems in the Slum Settlements of Nairobi: Implications for Slum Upgrading Programmes. Available online: https://www.researchgate.net/publication/235994708_land_tenure_systems_ in_the_informal_settlements_of_nairobi_implications_for_slum_upgrading (accessed on 20 August 2019).

45. Leah, M. Kenyan Government Initiatives in Slum Upgrading. 2011. Available online: http://journals. openedition.org/eastafrica/534 (accessed on 12 May 2019).

46. Elmhirst, R. Space, identity politics and resource control in Indonesia's transmigration programme. Political Geogr. 1999, 18, 813-835. [CrossRef]

47. Amis, P.; Kumar, S. Urban economic growth, infrastructure and poverty in India: Lessons from Visakhapatnam. Environ. Urban. 2000, 12, 185-196. [CrossRef]

48. Rashid, S.F. Strategies to reduce exclusion among populations living in urban slum settlements in Bangladesh. J. Health Popul. Nutr. 2009, 27, 574-586. [CrossRef]

49. De Zoysa, I.; Bhandari, N.; Akhtari, N.; Bhan, M.K. Careseeking for illness in young infants in an urban slum in India. Soc. Sci. Med. 1998, 47, 2101-2111. [CrossRef]

50. Beall, J. Globalization and social exclusion in cities: Framing the debate with lessons from Africa and Asia. Environ. Urban. 2002, 14, 41-51. [CrossRef]

51. Werlin, H. The Slum Upgrading Myth. Urban Stud. 1999, 36, 1523-1534. [CrossRef]

52. Tsenkova, S.; Potsiou, C.; Badyina, A. Self-Made Cities: In Search of Sustainable Solutions for Informal Settlements in the United Nations Economic Commission for Europe Region; United Nations Publications: Geneva, Switzerland, 2009; Available online: https://www.unece.org/fileadmin/DAM/hlm/documents/Publications/SelfMadeCities. pdf (accessed on 20 January 2019).

53. Cytonn Real Estate. Nairobi Metropolitan Area Residential Report 2017/2018. 2018. Available online: https://www.cytonn.com/downloads/nairobi-metropolitan-area-residential-report-2017-2018 (accessed on 15 January 2019).

54. Mwaniki, D.; Wamuchiru, E.; Mwau, B.; Opiyo, R. Urbanisation, Informality and Housing Challenge in Nairobi: A Case of Urban Governance Failure? Available online: https:/www.rc21.org/en/wp-content/ uploads/2014/12/G2_Dennis-Mwaniki.pdf (accessed on 21 July 2020).

55. Turner, J.F.C.; Fichter, R. Freedom to Build; Macmillan: New York, NY, USA, 1972.

56. State Department of Housing \& Urban Development. Civil Servants Housing Scheme. 2020. Available online: https://housingandurban.go.ke/the-civil-servants-housing-scheme-fund-cshsf/ (accessed on 12 January 2020). 
57. State Department of Housing \& Urban Development. 500,000 Affordable Homes Programme; Delivery Framework Overview. 2020. Available online: https://bomayangu.go.ke/downloads/20190624_Affordable_ Housing_Programme_-_Full_prezzy_-_Draft_v09.pdf (accessed on 24 April 2020).

58. Seeta, S. Construction Financing in Africa's Affordable Housing Sectors: A Critical Gap; Testing the Assumptions in Kenya's Affordable Housing Programme. Centre for Affordable Housing Finance in Africa (CAHF), 2019. Available online: http://housingfinanceafrica.org/app/uploads/Shah_Case-Study-16_ Construction-Financing-FINAL.pdf (accessed on 20 March 2020).

59. United Nations. Policy Paper 1: The Right to the City and Cities for All. 2017. Available online: http: //habitat3.org/wp-content/uploads/Habitat\%20III\%20Policy\%20Paper\%201.pdf (accessed on 15 April 2020).

60. United Nations. Cities of Opportunity: Partnerships for an inclusive and sustainable future. In Proceedings of the Fifth Asia-Pacific Urban Forum, UN Conference Centre, Bangkok, Thailand, 20-25 June 2011; Available online: https://www.unescap.org/sites/default/files/report.pdf (accessed on 16 May 2020).

61. UN-Habitat. The Role of Government in the Housing Market: The Experiences from Asia; UN-Habitat: Nairobi, Kenya, 2008; ISBN 978-92-1-131997-2.

62. Edgar, P. Competing Imaginaries of Empowerment in African Cities. In Afritecture. Building Social Change; Andres, L., Ed.; Hatje Cantz Verlag: Ostfildern, Germany, 2012; pp. 104-113.

63. Erhard, E. Learning from informal markets: Innovative approaches to land and housing provision. Dev. Pract. 2001, 11, 292-307. [CrossRef]

64. Bernard, N.; Claudia, T. Harnessing the Real Estate Market for Equitable Affordable Housing Provision through Land Value Capture: Insights from San Francisco City, California. Sustainability 2019, 11, 3649. [CrossRef]

65. Fainstein, S.S. Land Value Capture and Justice, in: "Inclusionary Housing in International Perspective: Affordable Housing, Social Inclusion, and Land Value Recapture"; Lincoln Institute of Land Policy: Washington, DC, USA, 2012.

66. Bernard, N.; Claudia, T. Harnessing the real estate market for equitable affordable housing provision: Insights from the city of Santa Monica, California. Hous. Stud. 2020, 1-36. [CrossRef]

67. Ingram, G.K.; Hong, Y. Value Capture and Land Policies; Lincoln Institute of Land Policy: Cambridge, MA, USA, 2012; Available online: https://www.lincolninst.edu/sites/default/files/pubfiles/value-capture-and-landpolicies-chp.pdf (accessed on 21 July 2020).

68. Agyemang, F.; Morrison, N. Recognising the barriers to securing affordable housing through the land use planning system in Sub-Saharan Africa: A perspective from Ghana. Urban Stud. 2017, 55, 2640-2659. [CrossRef]

69. Will, J. Sustainable Development: Slums, Informal Settlements, and the Role of Land Policy. 2018. Available online: https://www.lincolninst.edu/publications/articles/sustainable-development (accessed on 7 December 2019).

70. Faye, I.; Gajigo, O.; Mutambatsere, E. Large Scale Agribusiness Investments and Implications in Africa: Development Finance Institutions' Perspectives; Working Paper Series No.193; African Development Bank: Tunis, Tunisia, 2013.

71. Vinit, M. Enabling Slum Redevelopment in Mumbai: Policy Paradox in Practice. Hous. Stud. 2001, 16, 791-806. [CrossRef]

72. Graham, A. Tackling poverty in Nairobi's informal settlements: Developing an institutional strategy. Environ. Urban. 1995, 7, 85-108.

73. Taylor, L. Value Capture through Voluntary Planning Agreements Part 1, in In Focus, Lindsay Taylor Lawyers. 2016. Available online: https://www.lindsaytaylorlawyers.com.au/in_focus/value-capture-throughvoluntary-planning-agreements/ (accessed on 12 October 2019).

74. UN-Habitat. Participatory Slum Upgrading and Prevention Programme. 2009. Available online: http: //Mirror.Unhabitat.Org/Downloads/Docs/7927_54964_Narrative_Report.Pdf (accessed on 7 December 2019).

75. Republic of Kenya. The Constitution of Kenya 2010. Available online: http://cn.invest.go.ke/wp-content/ uploads/2018/10/The-Constitution-of-Kenya-2010.pdf (accessed on 10 June 2019).

76. Republic of Kenya. The Physical and land Use Planning Act of 2019. Available online: http://kenyalaw. org/k1/fileadmin/pdfdownloads/Acts/2019/PhysicalandLandUsePlanningAct_No13of2019.pdf (accessed on 10 June 2019). 
77. Republic of Kenya. The Land Act 2012, No. 6 of 2012. Available online: http://www.parliament.go.ke/sites/ default/files/2017-05/LandAct2012.pdf (accessed on 10 June 2019).

78. Republic of Kenya. The Land Registration Act 2012, No. 3 of 2012. Available online: https://eregulations. invest.go.ke/media/Land_Registration_Act__No_3_of_2012_.pdf (accessed on 10 June 2019).

79. Republic of Kenya. The National Land Commission Act 2012, No. 5 of 2012. Available online: http://kenyalaw. org/kl/fileadmin/pdfdownloads/Acts/National_Land_Commission_Act__No_5_of_2012_.pdf (accessed on 10 June 2019).

80. Republic of Kenya. The Community Land Act No. 27 of 2016. Available online: http://kenyalaw.org/k1/ fileadmin/pdfdownloads/Acts/CommunityLandAct_27of2016.pdf (accessed on 10 June 2019).

81. Republic of Kenya. The Urban Areas and Cities Act, No. 13 of 2011. Available online: http://www.parliament. go.ke/sites/default/files/2017-05/UrbanAreasandCitiesAct_No13of2011.pdf (accessed on 10 June 2019).

82. Winnie, M. “Urban Slums Reports: The Case of Nairobi, Kenya." Understanding Slums: Case Studies for the Global Report on Human Settlements 2003. 2003. Available online: https://www.ucl.ac.uk/dpu-projects/ Global_Report/pdfs/Nairobi.pdf (accessed on 15 May 2018).

83. Otiso, K.M. Profile of Nairobi, Kenya. In Berkshire Encyclopedia of Sustainability 9/10: Afro-Eurasia: Assessing Sustainability; Kotze, L., Morse, S., Eds.; Berkshire Publishing Group: Great Barrington, MA, USA, 2012.

84. Kenya National Bureau of Statistics. 2019 Kenya Population and Housing Census; Volume II: Distribution of Population by Administrative Units. 2019. Available online: https://www.knbs.or.ke/?wpdmpro=2019-kenyapopulation-and-housing-census-volume-ii-distribution-of-population-by-administrative-units (accessed on 20 February 2020).

85. Department for International Development (DFID). Regulatory Guidelines for Urban Upgrading Project: A Case Study of Mavoko-Kenya. 2003. Available online: https://assets.publishing.service.gov.uk/media/ 57a08cf1ed915d3cfd001700/R7850_Mavokocasestudy_RGUU3.pdf (accessed on 19 December 2019).

86. Kibera.org.uk. Kibera Facts \& Information. Available online: https://www.kibera.org.uk/facts-info/ (accessed on 26 February 2020).

87. Amélie, D.; Sophie, T. Kibera: The Biggest Slum in Africa? Les Cahiers de l'Afrique de l'Est 2011, 44, $22-33$.

88. Map Kibera Project-Maps and Statistics. Available online: http://mapkiberaproject.yolasite.com/maps-andstatistics.php (accessed on 2 June 2019).

89. Amnesty International. Amnesty International Report 2009: The State of the World's Human Rights; Amnesty International Publication: London, UK, 2009; Available online: https:/www.amnesty.org/download/ Documents/POL100022009ENGLISH.PDF (accessed on 12 May 2019).

90. KNCHR. A Report Submitted to The High Court of Kenya (Nairobi) by the Kenya National Commission on Human Rights on the Implementation of Petition No. 304 of 2015 Allocation of Housing Units in Kibera Soweto East Zone 'A' Redevelopment Project under the Kenya Slum Upgrading Programme. 2018. Available online: http://Knchr.Org/Portals/0/Idp\%20work/Kibera\%20housing\%20project.Pdf?Ver=2018-06-07-105134690 (accessed on 31 January 2020).

91. Crawford, C. Density, Affordable Housing and Social Inclusion: A Modest Proposal for Cape Town. J. Comp. Urban Law Policy 2017, 1, 7. Available online: https://readingroom.law.gsu.edu/jculp/vol1/iss1/7 (accessed on 15 January 2020).

92. United Nations, Department of Economic and Social Affairs, Population Division. The World's Cities in 2018-Data Booklet (ST/ESA/SER.A/417). 2018. Available online: https://www.un.org/en/events/citiesday/ assets/pdf/the_worlds_cities_in_2018_data_booklet.pdf (accessed on 5 June 2020).

93. Research International. Kibera Social and Economic Mapping: Household Survey Data; Government of Kenya: Nairobi, Kenya, 2015.

94. Schwartz, H.L.; Ecola, L.; Leuschner, K.J.; Kofner, A. Is Inclusionary Zoning Inclusionary? 2012. Available online: https://www.rand.org/content/dam/rand/pubs/technical_reports/2012/RAND_TR1231.pdf (accessed on 5 September 2018).

95. IQSK. The Quantity Surveyor. Off. J. Inst. Quant. Surv. Kenya 2019, 23, 41-45. Available online: https://iqskenya.org/wp-content/uploads/2020/01/IQSK-issue-29-\%E2\%80\%A2-Interactive-2-3.pdf (accessed on 12 December 2019).

96. Heather, T. Cost of Constructing a Home. Special Study for Housing Economics. 2015. Available online: https://www.nahbclassic.org/fileUpload_details.aspx?contentTypeID=3\&contentID= 248306\&subContentID=659949 (accessed on 25 May 2019). 
97. Central Bank of Kenya. Discount Window. 2020. Available online: https://www.centralbank.go.ke/rates/ discount-window/ (accessed on 4 June 2020).

98. Kieti, R.M. Urban Housing Affordability in Kenya. A Case Study of the Mortgage Housing Sector in Nairobi. Unpublished Ph.D. Thesis, University of Nairobi, Nairobi, Kenya, 2015.

99. Lydia, L. How Lucrative Is the Real Estate Sector. Available online: https://www.standardmedia.co.ke/article/ 2000090344/how-lucrative-is-the-real-estate-sector (accessed on 3 May 2020).

100. Francis, G. Percentage of Cost Breakdown between Labour, Materials and Contractor Profit in Construction. 2013. Available online: https://www.A4architect.Com/2013/04/Percentage-Of-Cost-Breakdown-BetweenLabour-Materials-And-Contractor-Profit-InConstruction/\#: \{\}:Text=An\%20average\%20residential\% 20house \%20construction,More\%20\%25\%20of\%20labour\%20than\%20others (accessed on 3 May 2020).

101. Central Bank of Kenya. Foreign Exchange Rates. 2020. Available online: https://www.centralbank.go.ke/ rates/forex-exchange-rates/ (accessed on 4 June 2020).

102. Keinvest. eRegulations: Building Plans and Permit Fees Evaluation Sheet. 2020. Available online: https://eregulations.invest.go.ke/procedure/252/90/step/455?1=en (accessed on 23 May 2020).

(C) 2020 by the authors. Licensee MDPI, Basel, Switzerland. This article is an open access article distributed under the terms and conditions of the Creative Commons Attribution (CC BY) license (http://creativecommons.org/licenses/by/4.0/). 